\title{
Middle Cretaceous Stratigraphy on the South and East Sides of the Uinta Basin, Northeastern Utah and Northwestern Colorado
}

\section{U.S. GEOLOGICAL SURVEY BULLETIN 1787-P}

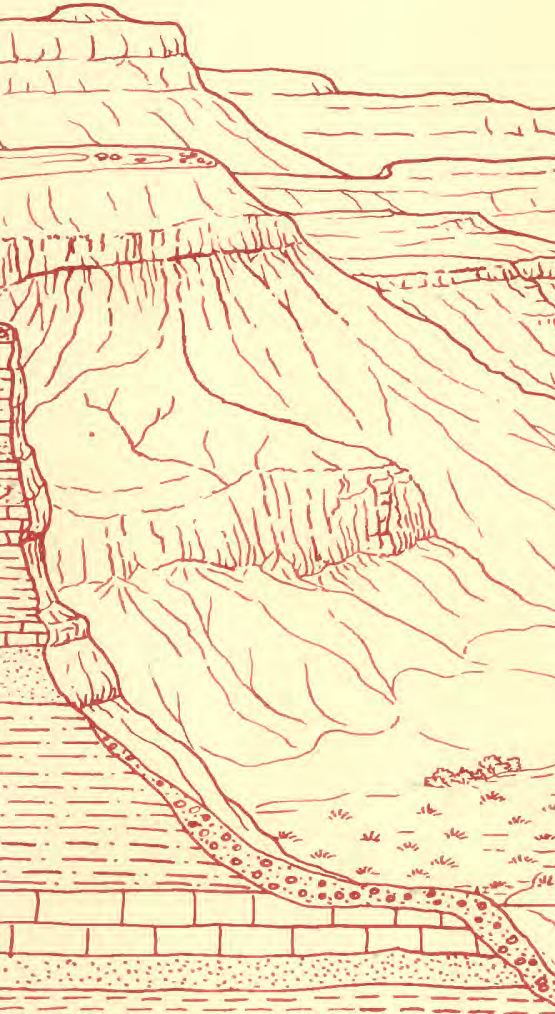

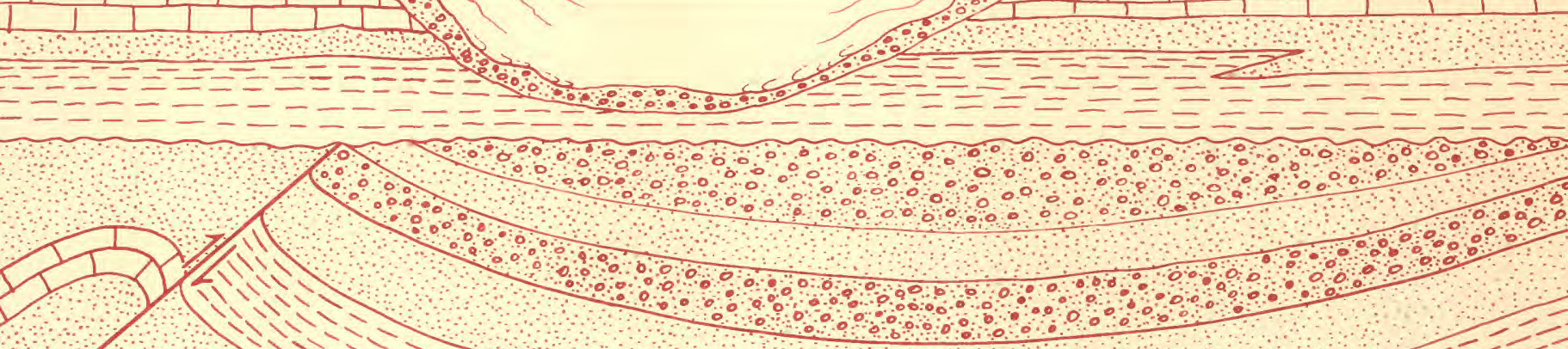



Chapter $\mathrm{P}$

\title{
Middle Cretaceous Stratigraphy on the South and East Sides of the Uinta Basin, Northeastern Utah and Northwestern Colorado
}

By C.M. MOLENAAR and W.A. COBBAN

\author{
A multidisciplinary approach to research studies of \\ sedimentary rocks and their constituents and the \\ evolution of sedimentary basins, both ancient and modern
}




\section{U.S. DEPARTMENT OF THE INTERIOR MANUEL LUJAN, JR., Secretary}

U.S. GEOLOGICAL SURVEY

Dallas L. Peck, Director

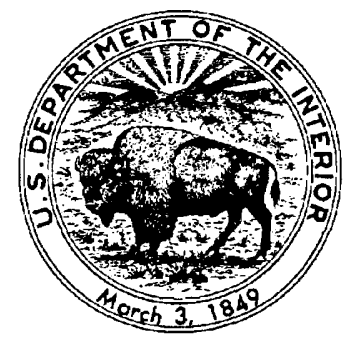

Any use of trade, product, or firm names in this publication is for descriptive purposes only and does not imply endorsement by the U.S. Government.

UNITED STATES GOVERNMENT PRINTING OFFICE: 1991

For sale by the

Books and Open-File Reports Section

U.S. Geological Survey

Federal Center

Box 25425

Denver, CO 80225

\section{Library of Congress Cataloging-in-Publication Data}

Molenaar, C, M.

Middle Cretaceous stratigraphy on the south and east sides of the Uinta

Basin, northeastern Utah and northwestern Colorado / by C.M. Molenaar and

W.A. Cobban.

p. $\quad \mathrm{cm}$. - (Evolution of sedimentary basins-Uinta and Piceance basins;

ch. P) (U.S. Geological Survey bulletin ; 1787-P)

Includes bibliographical references.

Supt. of Docs. no.: I 19.3: 1787-P

1. Geology, Stratigraphic-Cretaceous. 2. Rocks, Sedimentary-Uinta Basin (Utah and Colo.) 3. Geology-Uinta Basin (Utah and Colo.) 4. Uinta

Basin (Utah and Colo.) I. Cobban, William Aubrey, 1916-.

II. Title. III. Series. IV. Series: U.S. Geological Survey bulletin ; 1787-P.

QE75.B9 no. 1787-P.

[QE687]

$557.3 \mathrm{~s}-\mathrm{dc} 20$

[551.7'7'09792] 


\section{CONTENTS}

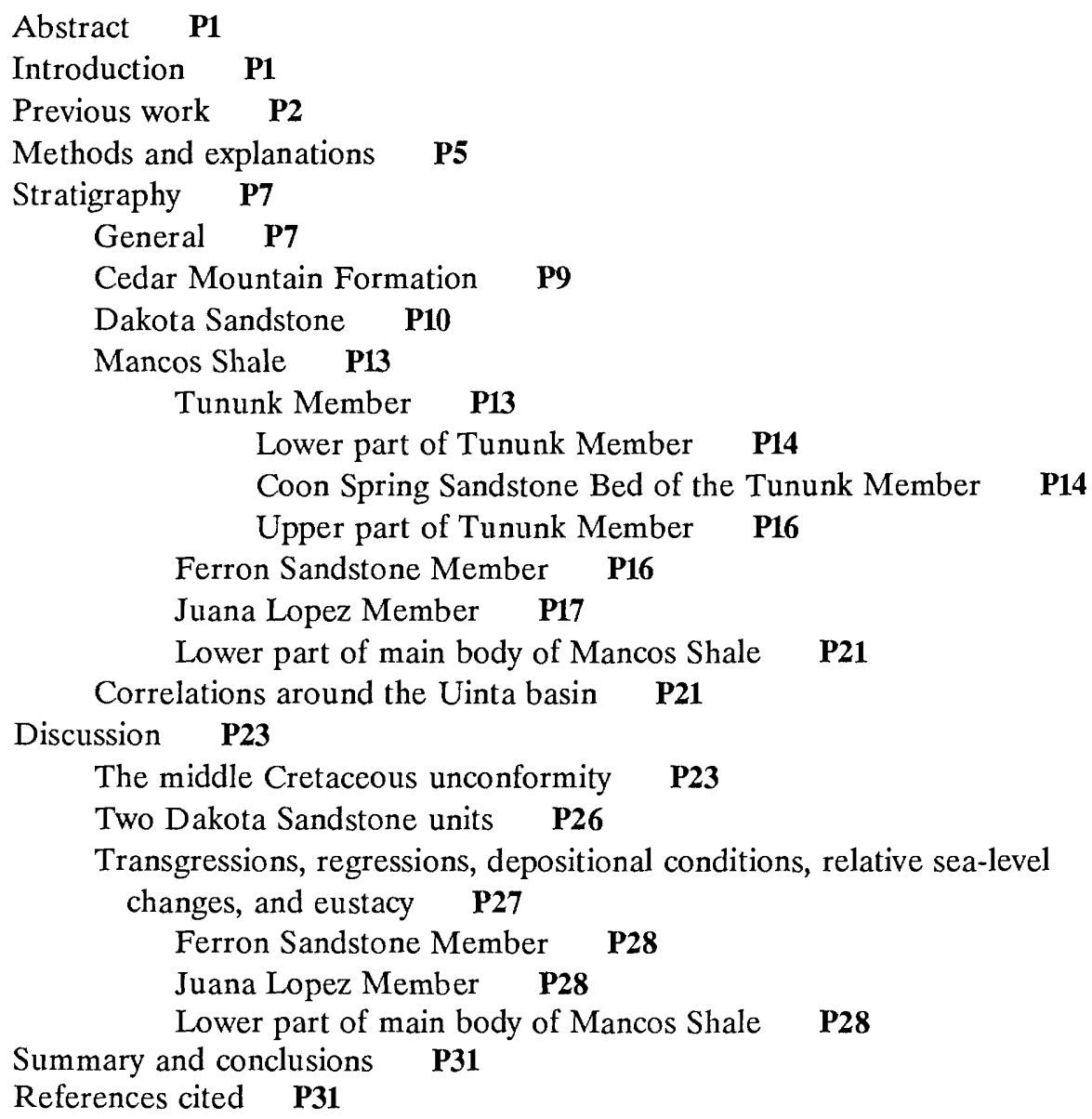

1. Stratigraphic correlation sections of middle Cretaceous rocks on the south and east sides of the Uinta basin, northeastern Utah and northwestern Colorado.

\section{FIGURES}

1-2. Maps showing:

1. Extent of Western Interior seaway during Late Cretaceous time $\mathbf{P 2}$

2. Outcrops of selected middle Cretaceous rocks, location of surface sections and drill holes used in study, and lines of cross sections $\quad$ P3

3. Chronostratigraphic diagram showing lithofacies and terminology relations on the south, north, and east sides of Uinta basin $\mathbf{P 4}$

4. Chart showing Cenomanian through Coniacian U.S. Western Interior molluscan fossil zones 
5-6. Stratigraphic correlation sections along:

5. South side of Uinta basin P11

6. East side of Uinta basin P12

7-8. Photographs showing:

7. Type section of Coon Spring Sandstone Bed P16

8. Contact of Tununk and Juana Lopez Members P17

9. Stratigraphic correlation section showing relations of the Ferron Sandstone Member near Ferron and the Ferron Sandstone and Juana Lopez Members near the Farnham dome $\mathbf{P 1 8}$

10-13. Photographs showing:

10. Cliff-forming Juana Lopez Member overlying Tununk Member P19

11. Cuesta-forming Juana Lopez Member overlying Ferron Sandstone Member P19

12. Basal transgressive sandstone of Juana Lopez Member P19

13. Close-up views of Juana Lopez Member P20

14-15. Stratigraphic correlation sections:

14. Along north side of Uinta basin $\mathbf{P 2 2}$

15. Along west side of Uinta basin $\mathbf{P 2 4}$

16. Map showing distribution and lithofacies of lower middle Turonian rocks $\mathbf{P 2 6}$

17. Chart showing eustatic sea-level curves for most of middle Cretaceous time $\mathbf{P 2 7}$

18-19. Maps showing distribution and lithofacies of:

18. Rocks deposited at the end of middle Turonian time

19. Upper Turonian rocks $\mathbf{P 3 0}$

P29

\section{TABLES}

1. Control points used in study $\mathbf{P 6}$

2. Age-diagnostic fossil collections $\mathbf{P 8}$

3. Type section of Coon Spring Sandstone Bed of the Tununk Member of the Mancos Shale P15

CONVERSION FACTORS FOR SOME SI METRIC AND U.S. UNITS OF MEASURE

\begin{tabular}{|c|c|c|}
\hline To convert from & To & Multiply by \\
\hline Feet $(\mathrm{ft})$ & Meters (m) & 0.3048 \\
\hline Miles (mi) & Kilometers (km) & 1.609 \\
\hline Pounds (lb) & Kilograms (kg) & 0.4536 \\
\hline Degrees Fahrenheit $\left({ }^{\circ} \mathrm{F}\right)$ & Degrees Celsius $\left({ }^{\circ} \mathrm{C}\right)$ & Temp ${ }^{\circ} \mathrm{C}=\left(\operatorname{temp}{ }^{\circ} \mathrm{F}-32\right) / 1.8$ \\
\hline
\end{tabular}




\title{
Middle Cretaceous Stratigraphy on the South and East Sides of the Uinta Basin, Northeastern Utah and Northwestern Colorado
}

\author{
By C.M. Molenaar and W.A. Cobban
}

\begin{abstract}
Middle Cretaceous rocks (Aptian to Coniacian) on the south side of the Uinta basin include the nonmarine Cedar Mountain Formation and Dakota Sandstone and the lower part of the overlying marine Mancos Shale. The lower part of the Mancos comprises the Tununk, Ferron Sandstone, and Juana Lopez Members and part of the main body of the Mancos Shale. The aggregate thickness of these rocks is $800-1,000 \mathrm{ft}(240-300 \mathrm{~m})$ over most of the area but increases to as much as $2,400 \mathrm{ft}(730 \mathrm{~m})$ under the Wasatch Plateau to the west. Detailed correlations using outcrop and drill-hole data indicate that (1) the Mancos Shale unconformably overlies the Cedar Mountain Formation over most of the area, (2) the Dakota Sandstone, where present, probably overlies and onlaps the unconformity, (3) the middle Turonian Ferron Sandstone Member grades southeastward into siltstone of the Tununk Member between Price and Green River, Utah, and (4) southeast of where the Ferron grades into the Tununk, the cuesta-forming upper Turonian Juana Lopez Member, which was previously mapped as Ferron Sandstone Member in the study area, overlies the Tununk Member.

Correlations of middle Cretaceous rocks on the south side of the basin with coeval rocks on the north side of the basin using drill-hole logs along the east side indicate that (1) the unconformity at the base of the Mancos Shale on the south side is the same as the unconformity that separates the Mowry Shale from the overlying Frontier Formation on the north side, (2) the lower half of the Tununk Member on the south side, including the Coon Spring Sandstone Bed (new name) of the Tununk, onlaps the unconformity to the north, and (3) the Mowry Shale grades southward into the Dakota Sandstone on the north side of the basin and the Dakota in turn grades southward into the upper part of the Cedar
\end{abstract}

Manuscript approved for publication February 6, 1990
Mountain Formation. The Dakota on the north side is older than the Dakota on the south side and separated from it by an unconformity.

\section{INTRODUCTION}

The area considered in this report lies along the south and east flanks of the present Uinta basin. During middle Cretaceous time, this area was on the west side of the Western Interior seaway (fig. 1) not far from the Sevier orogenic belt, which bounded the Western Interior basin on the west. Cretaceous rocks crop out along the north and south sides of the Uinta basin and extend eastward into northwestern Colorado (fig. 2). Molenaar and Wilson (1990) described and correlated the middle Cretaceous rocks around the Uinta Mountains on the north side of the basin. This report extends the stratigraphic study of middle Cretaceous rocks to the south and east sides of the basin.

Middle Cretaceous rocks (upper Lower and lower Upper Cretaceous) discussed in this report are, in ascending order, the Cedar Mountain Formation, Dakota Sandstone, and lower part of the Mancos Shale, which comprises the Tununk, Ferron Sandstone, and Juana Lopez Members. The Dakota and lower part of the Mancos were deposited during a major transgressiveregressive depositional cycle and the lower transgressive part of the next depositional cycle. Subsurface correlations indicate that fairly uniform and stable tectonic conditions existed over most of the study area except for the effects of an early Late Cretaceous high or peripheral bulge that are most noticeable in northeastern Utah, but which extend southward into east-central Utah. West of the Farnham dome (fig. 2), a faulted structure on the north plunge of the San Rafael uplift, the middle Cretaceous section thickens rapidly westward 


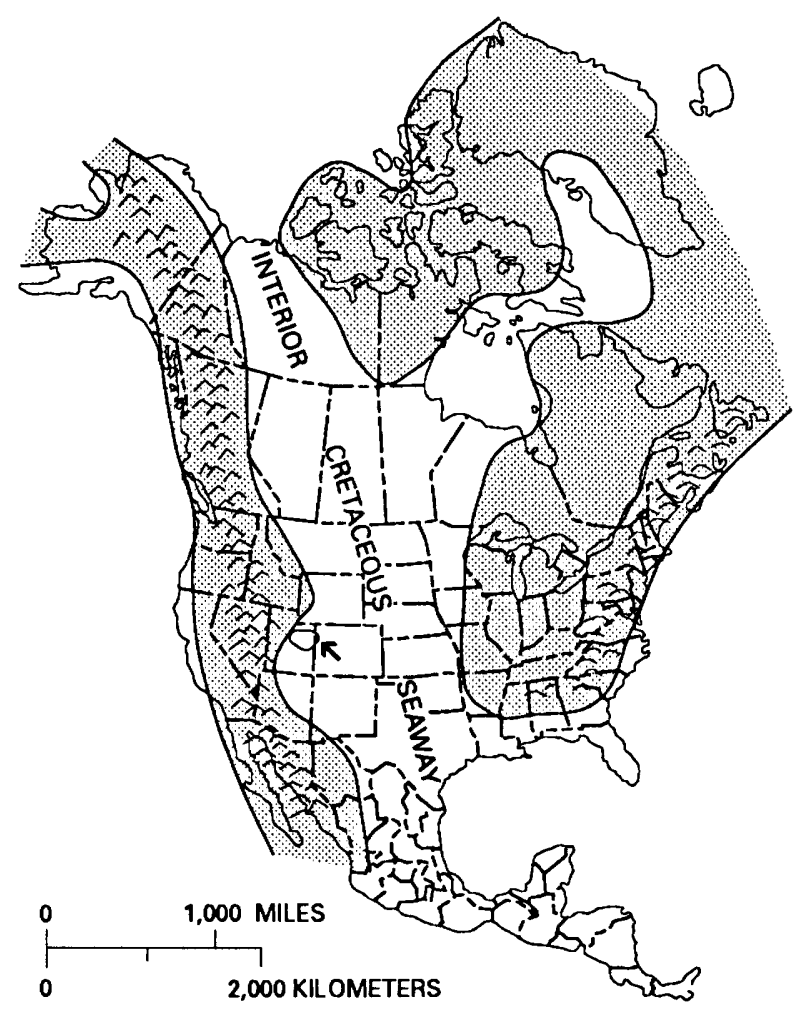

Figure 1. Extent of Western Interior epicontinental seaway during Late Cretaceous (late early Turonian) time. Arrow points to location of present-day Uinta basin. Modified from Williams and Stelck (1975) with permission of Geological Survey of Canada.

into a structural foredeep. Middle Cretaceous rocks crop out almost continuously along the south side of the Uinta basin from the Farnham dome eastward into Colorado (fig. 2). The lower part of the sequence is nonmarine and unconformably overlain by marine rocks, most of which are shale and are poorly exposed. Previously, the stratigraphic relations of the rocks in these areas were poorly understood. Numerous measured sections of selected parts of the marine section, good molluscan biostratigraphic control, and many drill-hole logs provide data to correlate the mostly marine part of the sequence across the entire south and east sides of the Uinta basin. The purpose of this report is to (1) describe the stratigraphic sequence, (2) describe the relationships between these rocks across the south flank of the Uinta basin by integrating surface and subsurface data, (3) correlate these rock units along the east side of the basin, by using drill-hole logs, with the Frontier Formation and associated rocks on the north side of the basin as described by Molenaar and Wilson (1990), and (4) discuss the marine transgressions and regressions as they relate to regional tectonic events and global eustatic sea-level changes. Figure 3 shows a comparison of stratigraphic terminology and time relations of middle
Cretaceous rocks on the south, north, and east sides of the Uinta basin. The interpretation of stratigraphic relations of some of the rock units is different from those previously reported.

Acknowledgments.-E.A. Merewether helped collect some of the megafossils and J.K. Baird digitized the drill-hole geophysical logs. In addition, M.A. Kirschbaum provided some megafossil data for the Coon Spring Sandstone Bed. The authors gratefully acknowledge this assistance. The report benefited from constructive criticisms of T.D. Fouch and Fred Peterson, who reviewed the manuscript.

\section{PREVIOUS WORK}

Middle Cretaceous rocks are included on several geologic maps of the outcrop belt along the south side of the Uinta basin but are only generally described (Dane, 1935; Fisher and others, 1960; Hintze and Stokes, 1964; Williams, 1964; Doelling, 1985; Gaultieri, 1988; Witkind, 1988). No detailed stratigraphic studies have been published of the lower part of the Mancos Shale. More attention has been given to the underlying nonmarine Cretaceous rocks, primarily because these rocks are better exposed and closer to the underlying uraniumbearing Morrison Formation and the overlying, coalbearing Mesaverde Group, which is well exposed along the prominent Book Cliffs. Stokes (1944) first reported on Lower Cretaceous rocks of the Colorado Plateau and, in a later report (1952), presented paleontologic age interpretations. Quigley (1959) showed a drill-hole log correlation section and discussed the stratigraphic relations of the lower part of the Mancos Shale, Dakota Sandstone, and the Cedar Mountain and Morrison Formations from the Rangely area to Grand Valley on the east side of the Uinta basin. Young (1960) presented a regional synthesis of the Lower Cretaceous Cedar Mountain Formation (of his Dakota Group) and Upper Cretaceous Dakota Sandstone (his Naturita Formation of his Dakota Group). Craig (1981) discussed some regional aspects of the Lower Cretaceous Cedar Mountain and Burro Canyon Formations.

Hale (1972) and Ryer and McPhillips (1983) described and correlated the Ferron Sandstone Member along Castle Valley south of Price beyond the primary area of this investigation, but they included subsurface correlation sections from the Farnham dome area to the west and northwest under the Wasatch Plateau. Cotter (1975) described and correlated sandstone units of the Ferron Member from the Farnham dome southeast to about halfway to Green River and also southwest from the Farnham dome. Molenaar (1975) suggested that the unit mapped as Ferron Sandstone Member in eastcentral Utah is more like the Juana Lopez Member and is younger than the Ferron to the northwest. 


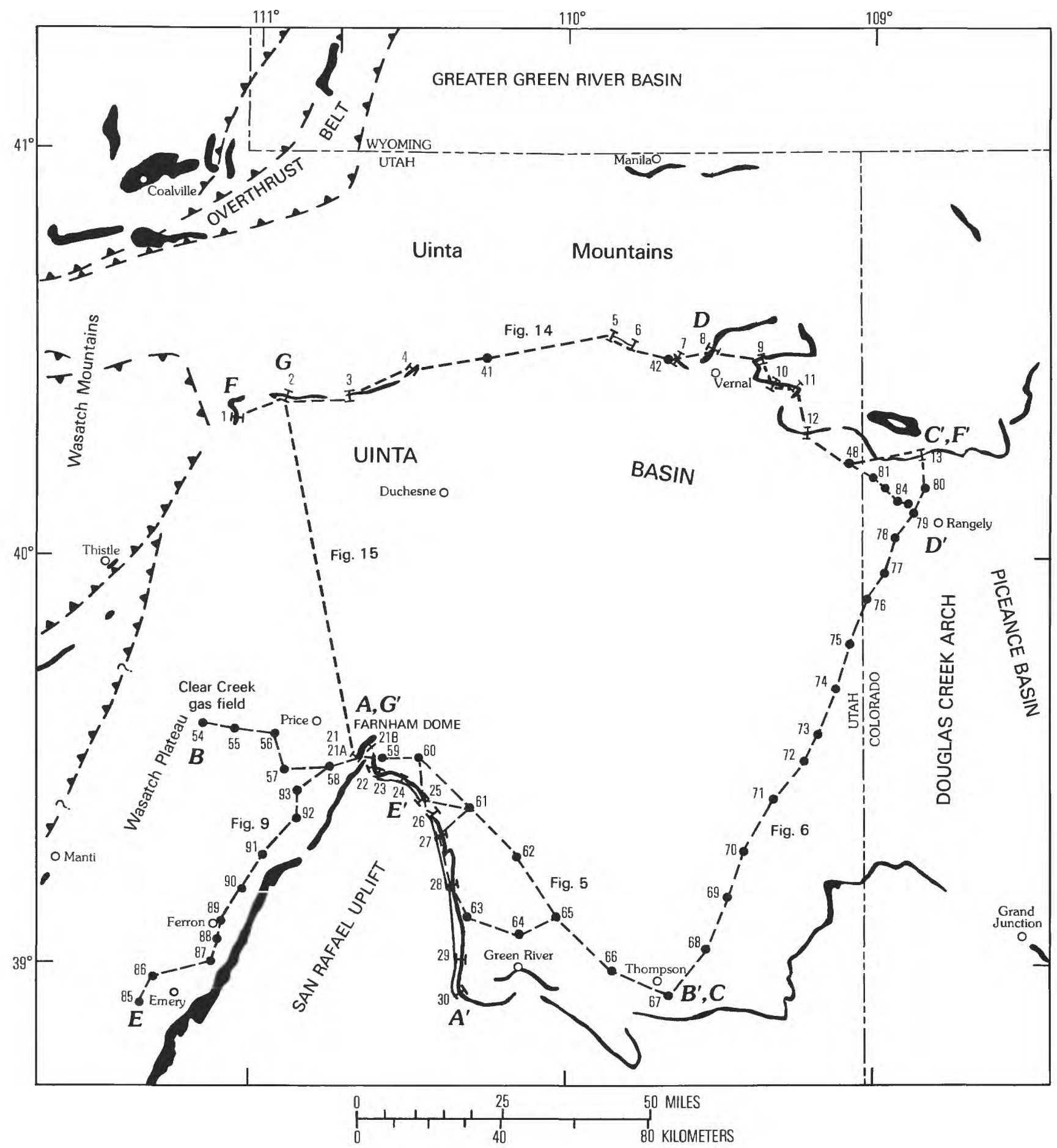

Figure 2. Outcrops of selected middle Cretaceous rocks (solid), locations of surface sections (bars), and drill holes (solid circles) used in study, and lines of correlation sections (dashed). Solid pattern on north side of Uinta basin indicates Frontier Formation, on south side of basin indicates Ferron Sandstone and Juana Lopez Members of the Mancos Shale, and on west side (Thistle and Manti areas) indicates coeval middle Cretaceous rocks. Thrust faults indicated by dashed lines with sawteeth on upper plate; queried (?) where uncertain. 


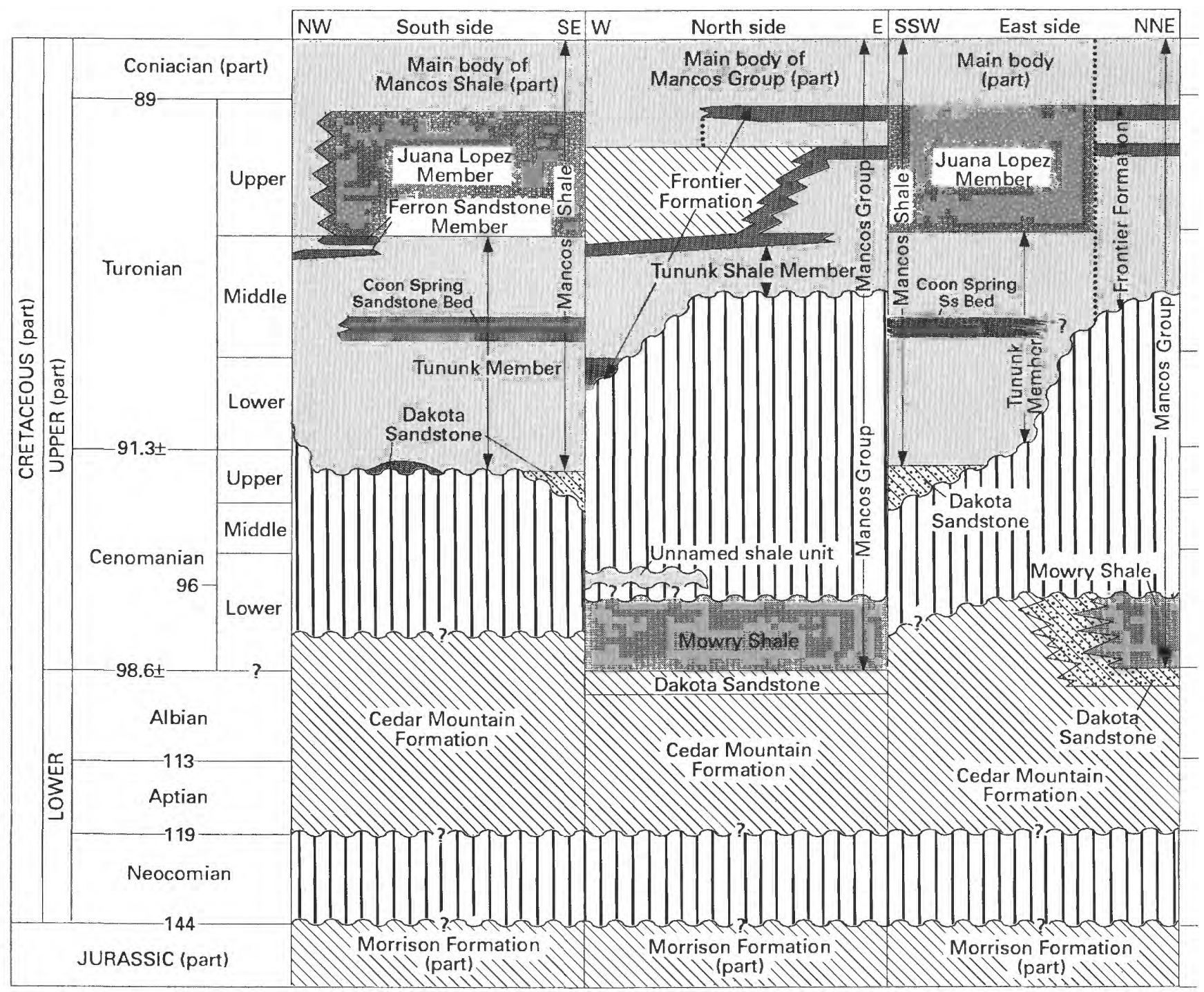

EXPLANATION

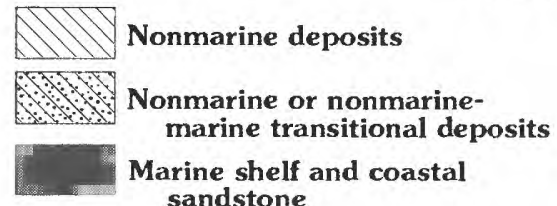

sandstone

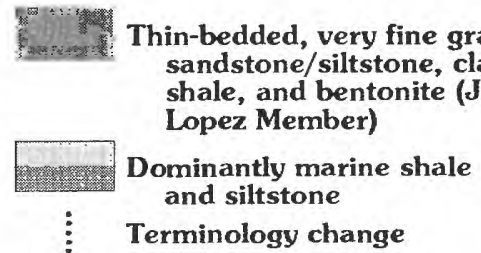

in-bedded, very fine grained sandstone/siltstone, clay (Juana minantly marine shale

Terminology change

Figure 3. Chronostratigraphic diagram showing lithofacies and terminology relations on the south, north, and east sides of Uinta basin. South side is based on surface and subsurface data and extends southeastward from area of Farnham dome. North side is based on surface data from Molenaar and Wilson (1990), and east side is based on subsurface correlations. Vertical interval on time scale is not uniform. Cenomanian-Albian boundary is from Cobban and Kennedy (1989). Numbers within and between stage boundaries refer to million years before present (Ma); from Obradovich and Cobban (1975) and J.D. Obradovich (oral commun., 1989) above the Albian and from Palmer (1983) below the Albian. Recent work by Cobban and Kennedy indicates that the Mowry Shale is partly or totally early Cenomanian in age. 
Katich (1956) interpreted Cretaceous fauna and biostratigraphy of eastern Utah, and Cobban (1976) presented the ammonite record west and northwest of Green River, Utah, including the west side of the San Rafael uplift. Lessard (1973) reported on the microfauna from two measured sections in the study area of the Tununk Member of the Mancos Shale. In a regional report on Upper Cretaceous rocks of central and east-central Utah, Fouch and others (1983) synthesized much of the marine and nonmarine biostratigraphic and lithofacies data for middle Cretaceous rocks. In a regional study, of which northeastern Utah was a part, Merewether and Cobban (1986) described chronostratigraphic and regional lithofacies patterns of middle Cretaceous rocks for several time periods.

\section{METHODS AND EXPLANATIONS}

The combination of data from surface sections and drill-hole logs adds immeasurably to detailed stratigraphic studies. If the quality of outcrops is good, surface sections are much better than drill-hole logs for interpreting details of lithology, contact relations, bedding features, and depositional environments. On the other hand, drill-hole logs are generally much better for measuring thicknesses, correlating marker beds in shale sections, and showing lateral relations of subjacent lithologic units. Thus, the two types of data complement each other.

In this study, drill holes are near enough to some of the surface sections so that a good calibration could be made. Key beds could be correlated using drill-hole logs across the entire south and east flanks of the Uinta basin. Thus, the important relations discussed in this report can be shown or interpreted with confidence.

In order to show details of lithology and correlations on the south side of the Uinta basin, 11 measured sections of the better exposed parts of the marine section of the middle Cretaceous were used (table 1, fig. 2, pl. 1). All sections were measured using a Jacob's staff, and, similar to the graphic system used by Molenaar and Wilson (1990), the measured surface sections shown on the plate are essentially grain-size plots except for some of the interbedded or intermixed rock types. These profiles are similar to idealized spontaneous potential (SP) logs of drill holes. Many of the SP logs, however, are greatly suppressed, and gamma-ray logs were used where available.

Marine molluscan fossils collected from or near many of the surface sections provide good biostratigraphic control. These partial sections of midCretaceous rocks were correlated into the subsurface to relate the surface exposures to the total mid-Cretaceous sequence as indicated by drill-hole geophysical logs. Precise correlation of surface exposures with drill-hole $\operatorname{logs}$ is a critical factor in determining the reliability of extended subsurface correlations of lithologic or timebounded units. Because numerous drill-hole logs are available for the study area and the stratigraphy is simple, subsurface correlations could be made across wide areas.

Subsurface correlations of many marker beds within the lower part of the Mancos Shale along the south and east sides of the basin were made primarily using resistivity or conductivity logs to provide a time framework in which to trace lithologic units. Markers or marker beds within the Mancos Shale are the result of obvious to subtle lithologic changes. Bentonite beds and sandstone-shale contacts are examples of obvious changes. Subtle changes, which also are reliable for long-distance correlations, are due to changes in content of carbonate, intermixed bentonite, and silt or sand within the shale section and possibly to differences in clay mineralogy. All these lithologic variations are indicated on resistivity or conductivity logs.

The curves of the drill-hole logs shown on plate 1 (sections $B-B^{\prime}, C-C^{\prime}, D-D^{\prime}$ ) were reconstructed by digitizing the original SP or gamma-ray logs and conductivity or resistivity logs. The original 1 in. $=100 \mathrm{ft}$-scale logs were digitized by hand tracing and recording the log curves. The logs were then printed at a lateral scale that allowed most of the correlated marker beds to be identified without being so large as to be impractical. The conductivity values were converted to a resistivity scale for convenience. In a few cases, the inflection point of a gamma-ray log does not precisely match the same inflection point on a resistivity or conductivity log, mostly because the two logs were recorded on different log runs or because distortions were introduced in digitizing or printing the original logs.

The datum used for the subsurface correlation sections $B-B^{\prime}$ and $C-C^{\prime}$ (pl. 1) was an upper marker bed, common to both sections, that is $200-400 \mathrm{ft}(60-120 \mathrm{~m})$ above the Juana Lopez-Ferron interval. This marker bed, similar to most marker beds, was probably a fairly flat surface at the time of deposition. The section along the south side of the basin (pl. 1, section $B-B^{\prime}$ ) includes a few surface sections that allow lithology to be related to the geophysical log curves and the biostratigraphic control to be projected into the subsurface. The positions of marker beds and the base of the Mancos Shale shown on some of these surface sections are based on projections from nearby drill holes.

Some of the surface sections used in this study were used by Molenaar and Wilson (1990) in a report on coeval rocks on the north side of the basin, and the numbering system of surface and subsurface control points (table 1) and the biostratigraphic data (table 2) is a continuation of their numbering system. 
Table 1. Control points used in study

[All control points in Utah except 13 and 76-84, which are in Colorado]

\begin{tabular}{|c|c|c|c|}
\hline $\begin{array}{c}\text { Control } \\
\text { point }\end{array}$ & Name & Location & County \\
\hline \multicolumn{4}{|c|}{ OUTCROP SECTIONS } \\
\hline 1 & Currant Creek & $\begin{array}{l}\text { NE/4 sec. } 36, \text { T. } 1 \text { S., R. } 11 \mathrm{~W} . \\
\text { NE/4 sec. } 1, \text { T. } 2 \text { S., R. } 11 \mathrm{~W} \text {. }\end{array}$ & $\begin{array}{l}\text { Wasatch } \\
\text { Wasatch }\end{array}$ \\
\hline 2 & Red Creek & SW/4 sec. 16, T. 1 S., R. 9 W. & Wasatch \\
\hline 3 & Farm Creek & SW/4 sec. 12 , T. 1 S., R. 8 W. & Duchesne \\
\hline 4 & Pigeon Water Creek & SE/4 sec. 24, T. 1 N., R. $6 \mathrm{~W}$ & Duchesne \\
\hline 5 & Grouse Creek & SW/4 sec. 13, T. 3 S., R. 18 E. & Uintah \\
\hline 6 & Deep Creek & SE $/ 4$ sec. 27, T. 3 S., R. 19 E. & Uintah \\
\hline 7 & Coal Mine Basin & NE $/ 4$ sec. 3, T. 4 S., R. 20 E. & Uintah \\
\hline 8 & Steinaker Reservoir & SE/4 sec. 35, T. 3 S., R. 21 E. & Uintah \\
\hline 9 & Jensen Wash & SE $/ 4$ sec. 6, T. 4 S., R. 23 E. & Uintah \\
\hline 10 & Dinosaur National Monument-W & SW/4 sec. 27 , T. 4 S., R. 23 E. & Uintah \\
\hline 11 & Dinosaur National Monument-E & SE/4 sec. 31 , T. 4 S., R. 24 E. & Uintah \\
\hline 12 & Cliff Creek & W/2 sec. 9 , T. 6 S., R. 24 E. & Uintah \\
\hline 13 & Blue Mountain & SE $/ 4$ sec. 5, T. 3 N., R. 102 W. & Moffat \\
\hline $21 \mathrm{~A}$ & Southwest side, Farnham dome & SW/4 sec. 15, T. 15 S., R. 11 E. & Carbon \\
\hline $21 B$ & North side, Farnham dome & SE/4 sec. 1, T. 15 S., R. 11 E. & Carbon \\
\hline 22 & Southeast side, Farnham dome & $\begin{array}{l}\text { SW/4 sec. } 30, \text { T. } 15 \text { S., R. } 12 \text { E. } \\
\text { SE } / 4 \text { sec. } 25 \text {, T. } 15 \text { S., R. } 11 \text { E. }\end{array}$ & $\begin{array}{l}\text { Carbon } \\
\text { Carbon }\end{array}$ \\
\hline 23 & Mounds Reef & SW/4 sec. 32, T. 15 S., R. 12 E. & Carbon \\
\hline 24 & Grassy Trail & NE/4 sec. 2 , T. 16 S., R. 12 E. & Emery \\
\hline 25 & North Cedar & NW/4 sec. 21 , T. 16 S., R. 13 E. & Emery \\
\hline 26 & Southeast Cedar & SE/4 sec. 35, T. 16 S., R. 13 E. & Emery \\
\hline 27 & Grassy & SE/4 sec. 24 , T. 17 S., R. 13 E. & Emery \\
\hline 28 & East side, Woodside dome & SE/4 sec. 32 , T. 18 S., R. 14 E. & Emery \\
\hline 29 & Cottonwood Wash & NW/4 sec. 1, T. 21 S., R. 14 E. & Emery \\
\hline 30 & I-70 road cut & N/2 sec. 2 , T. 22 S., R. 14 E. & Emery \\
\hline & & SE/4 sec. 35, T. 21 S., R. 14 E. & Emery \\
\hline & & SW/4 sec. 36, T. 21 S., R. 14 E. & Emery \\
\hline \multicolumn{4}{|c|}{ DRILL-HOLE LOGS } \\
\hline 41 & Gulf Oil Co. Cottonwood Wash Tribal No. 1 & Sec. 7, T. 1 N., R. 3 W. & Duchesne \\
\hline 48 & New World Oil Co. Max Pray Govt. No. 1 & Sec. 3, T. 7 S., R. 25 E. & Uintah \\
\hline 54 & Tenneco Oil Co. Clear Creek No. 1 & Sec. 17, T. 14 S., R. 7 E. & Carbon \\
\hline 55 & Occidental Petroleum Corp. Gordon Creek No. 1 & Sec. 19, T. 14 S., R. 8 E. & Carbon \\
\hline 56 & Amerada Petroleum Corp. USA-Abbott No. 1 & Sec. 29, T. 14 S., R. 9 E. & Carbon \\
\hline 57 & Shell Oil Co. North Springs Unit-1 & Sec. 27 , T. 15 S., R. 9 E. & Carbon \\
\hline 58 & Shell Oil Co. Miller Creek No. 1 & Sec. 26, T. 15 S., R. 10 E. & Carbon \\
\hline 59 & Equity Oil Co. Farnham No. 2 & Sec. 17, T. 15 S., R. 12 E. & Carbon \\
\hline 60 & Equity Oil Co. Sunnyside Unit-1 & Sec. 17, T. 15 S., R. 13 E. & Carbon \\
\hline 61 & Forest Oil Corp. Govt. Amold No. 25-1 & Sec. 25 , T. 16 S., R. 14 E. & Emery \\
\hline 62 & Gulf Oil Co. Norris Fed. No. 1 & Sec. 8, T. 18 S., R. 16 E. & Emery \\
\hline 63 & Carter Oil Co. Sphinx No. 1 and 1-A & Sec. 35, T. 19 S., R. 14 E. & Emery \\
\hline 64 & Kewanee Oil Co. State No. 1 & Sec. 17, T. 20 S., R. 16 E. & Emery \\
\hline 65 & Tenneco Oil Co. Butler Canyon Unit 33-12 & Sec. 33 , T. 19 S., R. 17 E. & Grand \\
\hline 66 & Continental Oil Co. Blaze Canyon Unit-1 & Sec. 7, T. 21 S., R. 19 E. & Grand \\
\hline 67 & Texaco, Inc. Thompson Unit-1 & Sec. 35, T. 21 S., R. 20 E. & Grand \\
\hline 68 & N-P Energy Co. Fed. No. 23-1 & Sec. 23 , T. 20 S., R. 21 E. & Grand \\
\hline 69 & Gulf Oil Co. Bookcliffs No. 2 & Sec. 4 , T. 19 S., R. 22 E. & Grand \\
\hline 70 & Sunray-Mid Continent Diamond Ridge U-3 & Sec. 25 , T. 17 S., R. 22 E. & Grand \\
\hline 71 & Tidewater Oil Co. Horse Point Unit 1-X & Sec. 14, T. 16 S., R. 23 E. & Grand \\
\hline 72 & Great Basins Black Horse Canyon U-1 & Sec. 17, T. 15 S., R. 24 E. & Uintah \\
\hline 73 & Natural Gas Corp. of Calif. Fed. No. $42-23$ & Sec. 23 , T. 14 S., R. 24 E. & Uintah \\
\hline 74 & Raymond Oil Co. Govt. No. 1 & Sec. 17, T. 13 S., R. 25 E. & Uintah \\
\hline 75 & Pacific Nat'l. Gas Expl.Co. Evac. Cr. No. 23-2-1 & Sec. 2, T. 12 S., R. 25 E. & Uintah \\
\hline 76 & Mitchell Energy Corp. Fed. G-2-2-104-5 & Sec. 2, T. 2 S., R. 104 W. & Rio Blanco \\
\hline 77 & Chomey Oil Co. Banta Ridge Unit-3 & Sec. 17, T. 1 S., R. 103 W. & Rio Blanco \\
\hline 78 & Chevron Oil Co. No. 1 Fed. (14-15) & Sec. 15, T. 1 N., R. 103 W. & Rio Blanco \\
\hline 79 & Chevron Oil Co. Raven A-5X & Sec. 30 , T. 2 N., R. 102 W. & Rio Blanco \\
\hline 80 & Pan American Petroleum Corp. Haley No. 1 & Sec. 4, T. 2 N., R. 102 W. & Rio Blanco \\
\hline 81 & Petro-Lewis Corp. Papaulus Fed. 9-25 & Sec. 25, T. 3 N., R. 104 W. & Moffat \\
\hline 82 & Petro-Lewis Corp. Coleman Fed. 2-5 & Sec. 5, T. 2 N., R. 103 W. & Moffat \\
\hline
\end{tabular}




\begin{tabular}{clll}
\hline $\begin{array}{c}\text { Control } \\
\text { point }\end{array}$ & \multicolumn{1}{c}{ Name } & \multicolumn{1}{c}{ Location } & County \\
\hline 83 & Stanolind Oil and Gas Co. Haygood A-9 & Sec. 15, T. 2 N., R. 103 W. & Moffat \\
84 & California Co. McLaughlin-9 & Sec. 24, T. 2 N., R. 103 W. & Moffat \\
85 & Willard Pease Drilling Co. Utah State-1Q & Sec. 16, T. 22 S., R. 5 E. & Sevier \\
86 & Vortt Expl. Co. Inc. Link Canyon-1 & Sec. 23, T. 21 S., R. 5 E. & Sevier \\
87 & Pacific Nat'1 Gas Ferron Unit 42-9 & Sec. 9, T. 21 S., R. 7 E. & Emery \\
88 & American Petrofina State-1 & Sec. 22, T. 20 S., R. 7 E. & Emery \\
89 & Pan American Pet. Ferron Unit-4 & Sec. 2, T. 20 S., R. 7 E. & Emery \\
90 & Hughes Brockbank Arneson-1 & Sec. 8, T. 19 S., R. 8 E. & Emery \\
91 & J.A. Minton Wilberg 1-X & Sec. 12, T. 18 S., R. 8 E. & Emery \\
92 & English Drilling Co. McMullin-1 & Sec. 12, T. 17 S., R. 9 E. & Emery \\
93 & English Drilling Co. Harrison-1 & Sec. 13, T. 16 S., R. 9 E. & Emery \\
\hline
\end{tabular}

Most of the work in this study was on the marine rocks; little work was done on the nonmarine Cedar Mountain Formation and Dakota Sandstone. However, the relation of the regional unconformity at the base of the marine section to the underlying nonmarine rocks over most of the area bears on controversial regional relations of the Cedar Mountain Formation and Dakota Sandstone. Therefore, these rocks are included in the study. In addition, for the sake of completeness and to show their geophysical log character, the two formations are shown on the correlation sections (pl. 1, sections $\left.B-B^{\prime}, C-C^{\prime}, D-D^{\prime}\right)$.

In this report, the term "shale" is used to mean any fine-grained rock composed of clay- or silt-size particles, without regard to fissility. To emphasize certain aspects of the shale, adjectives are used, such as clay shale or fissile clay shale.

Numerous age-diagnostic fossils collected in this study were related to the most recent sequence of Western Interior index fossils (fig. 4). It should be noted that middle Turonian fossil zone 20, Prionocyclus percarinatus, which has been recognized in eastern Wyoming, South Dakota, Nebraska, and western Minnesota, has not been reported in Utah, although strata of the zone are probably present inasmuch as there seems to be continuous deposition between strata containing fossils of zone 19, Collignoniceras woollgari, and zone 21, Prionocyclus hyatti. Based on the correlations (pl. 1), these zones are within 20-30 ft (6-9 m) of each other.

Another comment on fossil ages is that Cobban and Kennedy (1989) believe that Neogastroplites americanus, which was collected from the middle of the Mowry Shale on the north side of the Uinta basin (pl. 1, control point 8 , section $D-D^{\prime}$ ), and possibly $N$. cornutus, which was collected from near the base of the Mowry on the north side of the Uinta Mountains (Molenaar and Wilson, 1990), probably are early Cenomanian in age rather than late Albian as previously considered. In addition, Eicher (1965) reported calcareous planktonic foraminifers from the upper $26 \mathrm{ft}(8 \mathrm{~m})$ of the Mowry Shale along the Front Range in northern Colorado that indicate a Cenomanian age for at least that part of the Mowry. Hence, the Mowry Shale on correlation sections along the north and northeast sides of the basin (pl. 1, sections $\left.C-C^{\prime}, D-D^{\prime}\right)$ is shown as lower Cenomanian. Regardless of where the Albian-Cenomanian boundary lies, the absolute age at the top of the Mowry is about 96 $\mathrm{Ma}$ inasmuch as the radiometric ages assigned to the Mowry are from bentonite beds in the Mowry (Obradovich and Cobban, 1975).

In addition to the stratigraphic correlation sections of plate 1 , overview correlation sections of sections $B-B^{\prime}$ and $C-C^{\prime}$ (pl.1) are shown as figures 5 and 6 . Figure 5 is shorter than section $B-B^{\prime}$ on plate 1 because it eliminates the jogs that were made to incorporate several of the surface sections on section $B-B^{\prime}$ (fig. 2). Figure 5 also includes drill hole 62 , which is not included on section $B-B^{\prime}$ on plate 1 .

\section{STRATIGRAPHY}

\section{General}

Middle Cretaceous rocks considered in this study range in age from Albian and possibly Aptian through Turonian and into Coniacian. These rocks are about $800-1,000 \mathrm{ft}(240-300 \mathrm{~m})$ thick in most of the area, but they rapidly thicken to as much as $2,400 \mathrm{ft}(730 \mathrm{~m})$ in a structural foredeep west of the Farnham dome. In ascending order, these rocks comprise the nonmarine Cedar Mountain Formation, mostly nonmarine Dakota Sandstone, and lower part of the marine Mancos Shale on the south side of the Uinta basin. This part of the Mancos is subdivided into the Tununk Member, Coon Spring Sandstone Bed (new name) of the Tununk Member, Ferron Sandstone Member (present only in the western part of the area), Juana Lopez Member, and the lower part of the main body of the Mancos Shale (also called Blue Gate Member of the Mancos Shale south and west of the study area) (fig. 3). 
Table 2. Age-diagnostic fossil collections

[First number (underlined) of collection refers to fossil zone shown in figure 4. Second number is collection number keyed to figure 15 and plate 1. All localities in Utah except those in Moffat County, Colorado]

\begin{tabular}{|c|c|c|c|c|}
\hline $\begin{array}{l}\text { Fossil zone } \\
\text { and } \\
\text { collection } \\
\text { number }\end{array}$ & $\begin{array}{l}\text { USGS } \\
\text { Mesozoic } \\
\text { locality } \\
\text { number }\end{array}$ & Location & County & Age-diagnostic fossil and reference (if applicable) \\
\hline$\underline{3}-8$ & 25586 & Steinaker Draw & Uintah & Neogastroplites americanus (Reeside and Cobban, 1960) \\
\hline \multirow[t]{2}{*}{$\underline{21}-9$} & D9292 & SE $/ 4$ sec. 35 , T. 3 S., R. 21 E. & Uintah & Lopha bellaplicata (Shumard) \\
\hline & D9290 & SW/4 sec. 24 , T. 3 S., R. 21 E. & Uintah & $\begin{array}{l}\text { Prionocyclus hyatti (Stanton), Lopha bellaplicata } \\
\text { (Shumard) }\end{array}$ \\
\hline$\underline{23}-10$ & D9293 & SE/4 sec. 35 , T. 3 S., R. 21 E. & Uintah & $\begin{array}{l}\text { Scaphites warreni Meek and Hayden, Inoceramus dimidius } \\
\text { White }\end{array}$ \\
\hline$\underline{23}-11$ & D 11040 & SE/4 sec. 6, T. 4 S., R. 23 E. & Uintah & $\begin{array}{l}\text { Prionocyclus womingensis Meek, Scaphites sp., } \\
\text { Inoceramus dimidius White }\end{array}$ \\
\hline$\underline{23}-12$ & D1 1039 & NE/4 sec. 26, T. 4 S., R. 22 E. & Uintah & $\begin{array}{l}\text { Prionocyclus wyomingensis Meek, Scaphites warreni } \\
\text { Meek and Hayden, }\end{array}$ \\
\hline$\underline{23}-13$ & D1 1038 & SE/4 sec. 27, T. 4 S., R. 23 E. & Uintah & $\begin{array}{l}\text { Prionocyclus wyomingensis Meek, Inoceramus dimidius } \\
\text { White }\end{array}$ \\
\hline$\underline{22}-14$ & D12653 & SE/4 sec. 31, T. 4 S., R. 24 E. & Uintah & Inoceramus n. sp., Lopha lugubris (Conrad)? \\
\hline$\underline{24}-15$ & D12652 & SE/4 sec. 31 , T. 4 S., R. 24 E. & Uintah & $\begin{array}{l}\text { Scaphites whitfieldi Cobban, Inoceramus perplexus } \\
\text { Whitfield, Prionocyclus sp. }\end{array}$ \\
\hline$\underline{21}-16$ & D12788 & SW/4 sec. 9, T. 6 S., R. 24 E. & Uintah & $\begin{array}{l}\text { Prionocyclus hyatti (Stanton), Inoceramus cuvieri } \\
\text { (Sowerby) }\end{array}$ \\
\hline \multirow[t]{2}{*}{$\underline{22}-17$} & D1 1037 & SE/4 sec. 8 , T. 6 S., R. 24 E. & Uintah & Prionocyclus macombi Meek \\
\hline & D1 1036 & SW/4 sec. 9, T. 6 S., R. 24 E. & Uintah & $\begin{array}{l}\text { Prionocyclus wyomingensis Meek, Inoceramus dimidius } \\
\text { White, Lopha lugubris (Conrad) }\end{array}$ \\
\hline \multirow[t]{2}{*}{$\underline{22}-18$} & D1 1033 & SE/4 sec. 5, T. 3 N., R. 102 W. & Moffat & Prionocyclus macombi Meek, Inoceramus dimidius White \\
\hline & D12785 & NW/4 sec. 6, T. 3 N., R. 100 W. & Moffat & Lopha lugubris (Conrad) \\
\hline$\underline{22}-19$ & D12786 & NW/4 sec. 6, T. 3 N., R. 100 W. & Moffat & Prionocyclus macombi Meek, Inoceramus dimidius White \\
\hline$\underline{24}-20$ & D11034 & Sec. 5 , T. 3 N., R. 102 W. & Moffat & $\begin{array}{l}\text { Scaphites ferronensis Cobban, Prionocyclus } \\
\text { wyomingensis Meek, Inoceramus dimidius White }\end{array}$ \\
\hline \multirow[t]{2}{*}{$\underline{24}-21$} & D1 1035 & SE/4 sec. 5 , T. 3 N., R. 102 W. & Moffat & $\begin{array}{l}\text { Scaphites whitfieldi Cobban, Inoceramus perplexus } \\
\text { Whitfield }\end{array}$ \\
\hline & D8873 & SW/4 sec. 5, T. 3 N., R. 102 W. & Moffat & Prionocyclus wyomingensis Meek \\
\hline$\underline{23}-42$ & D12777 & SW/4 sec. 15, T. 15 N., R. 11 E. & Carbon & $\begin{array}{l}\text { Scaphites warreni Meek and Hayden, Lopha lugubris } \\
\text { (Conrad), Inoceramus dimidius White }\end{array}$ \\
\hline$\underline{21}-41$ & D12012-13 & SE/4 sec. 2 , T. 15 S., R. 11 E. & Carbon & Inoceramus howelli White, Inoceramus flaccidus White \\
\hline$\underline{21}-43$ & D12049 & NE/4 sec. 32 , T. 18 S., R. 9 E. & Emery & Prionocyclus hyatti Stanton \\
\hline$\underline{18 / 19}-44$ & D13026 & SE/4 sec. 1, T. 15 S., R. 11 E. & Carbon & Mytiloides cf. M. mytiloides (Mantell) \\
\hline$\underline{24}-45$ & D12985 & SW/4 sec. 30, T. 15 S., R. 12 E. & Carbon & Inoceramus perplexus Whitfield \\
\hline$\underline{22} / \underline{23}-46$ & D12984 & SW/4 sec. 30, T. 15 S., R. 12 E. & Carbon & Inoceramus dimidius White \\
\hline$\underline{22}-47$ & D12780 & SW/4 sec. 32 , T. 15 S., R. 12 E. & Carbon & Prionocyclus macombi Meek \\
\hline$\underline{21-48}$ & D12779 & SW/4 sec. 32 , T. 15 S., R. 12 E. & Carbon & Prionocyclus hyatti (Stanton) \\
\hline$\underline{23} / \underline{24}-49$ & D 12778 & NW/4 sec. 34, T. 15 S., R. 12 E. & Carbon & $\begin{array}{l}\text { Prionocyclus wyomingensis Meek, Inoceramus dimidius } \\
\text { White, Scaphites sp., Baculites yokoyamai Tokunaga } \\
\text { and Shimizu }\end{array}$ \\
\hline$\underline{21}-50$ & D12782 & NE/4 sec. 2 , T. 16 S., R. 12 E. & Emery & Lopha bellaplicata (Shumard)? \\
\hline$\underline{21}-51$ & D12781 & NE/4 sec. 2 , T. 16 S., R. 12 E. & Emery & $\begin{array}{l}\text { Prionocyclus hyatti (Stanton), Inoceramus howelli White, } \\
\text { Placenticeras pseudoplacenta Hyatt }\end{array}$ \\
\hline$\underline{22}-52$ & D12783 & NE/4 sec. 21, T. 16 S., R. 13 E. & Emery & Lopha lugubris (Conrad), Inoceramus dimidius White \\
\hline $21-5$ & D12022 & SW/4 sec. 27, T. $16 \mathrm{~S} .$, R. $13 \mathrm{E}$. & Emery & Prionocyclus macombi Meek, Coilopoceras colleti Hyatt \\
\hline$\underline{21}-54$ & D12020 & S/2 sec. 16, T. 16 S., R. 13 E. & Emery & Prionocyclus hyatti (Stanton) \\
\hline$\underline{21}-55$ & D12019 & S/2 sec. 16, T. 16 S., R. 13 E. & Emery & $\begin{array}{l}\text { Prionocyclus hyatti (Stanton), Lopha bellaplicata } \\
\text { (Shumard) }\end{array}$ \\
\hline$\underline{22}-56$ & D12775 & SE/4 sec. 35 , T. 16 S., R. 13 E. & Emery & Lopha lugubris (Conrad), Inoceramus dimidius White \\
\hline$\underline{22}-57$ & D12805 & SE/4 sec. 24, T. 17 S., R. 13 E. & Emery & $\begin{array}{l}\text { Prionocyclus macombi Meek, Lopha lugubris (Conrad), } \\
\text { Inoceramus dimidius White }\end{array}$ \\
\hline$\underline{19} / \underline{21}-58$ & D12784 & SE/4 sec. 24, T. 17 S., R. 13 E. & Emery & Rhynchostreon suborbiculatum (Lamarck) \\
\hline$\underline{23}-59$ & D12011 & SE/4 sec. 32 , T. 18 S., R. 14 E. & Emery & $\begin{array}{l}\text { Scaphites warreni Meek and Hayden, Inoceramus dimidius } \\
\text { White, Prionocyclus wyomingensis Meek }\end{array}$ \\
\hline
\end{tabular}




\begin{tabular}{|c|c|c|c|c|}
\hline $\begin{array}{l}\text { Fossil zone } \\
\text { and } \\
\text { collection } \\
\text { number }\end{array}$ & $\begin{array}{l}\text { USGS } \\
\text { Mesozoic } \\
\text { locality } \\
\text { number }\end{array}$ & Location & County & Age-diagnostic fossil and reference (if applicable) \\
\hline $22-60$ & D12010 & SE/4 sec. 32, T. 18 S., R. 14 E. & Emery & Lopha lugubris (Conrad), Inoceramus dimidius White \\
\hline $19 / 21-61$ & D12008 & SE/4 sec. 32, T. 18 S., R. 14 E. & Emery & Inoceramus flaccidus White, Exogyra sp. \\
\hline$\underline{19}-62$ & D12878 & Sec. 5, T. 19 S., R. 14 E. & Emery & Collignoniceras woollgari (Mantell) \\
\hline$\underline{22}-63$ & D12847 & NE/4 sec. 11, T. 21 S., R. 14 E. & Emery & Lopha lugubris (Conrad), Inoceramus dimidius White \\
\hline$\underline{22}-64$ & D12368 & SW/4 sec. 36, T. 21 S., R. 14 E. & Emery & $\begin{array}{l}\text { Prionocyclus macombi Meek, Lopha lugubris (Conrad), } \\
\text { Inoceramus dimidius White }\end{array}$ \\
\hline$\underline{19 / 21-65}$ & D12367 & SE/4 sec. 35, T. 21 S., R. 14 E. & Emery & $\begin{array}{l}\text { Rhynchostreon aff. } R \text {. suborbiculatum (Lamarck), Veniella } \\
\text { mortoni Meek and Hayden }\end{array}$ \\
\hline$\underline{19}-66$ & D12988 & SE/4 sec. 35, T. 21 S., R. 14 E. & Emery & Collignoniceras woollgari (Mantell) \\
\hline$\underline{13}-67$ & D12989 & N/2 sec. 2 , T. 22 S., R. 14 E. & Emery & Pycnodonte* newberryi (Stanton) \\
\hline$\underline{27}-68$ & D12992 & SE/4 sec. 6, T. 3 N., R. 100 W. & Moffat & Inoceramus (Cremnoceramus) deformis Meek \\
\hline
\end{tabular}

*Formerly called Gryphaea newberryi.

Numerous drill-hole logs along the south and east sides of the Uinta basin, augmented by lithologic and biostratigraphic data from outcrops along the south side of the basin (pl. 1, section A-A'), permit correlation of marine rocks throughout the south and east sides of the basin (pl. 1, sections $B-B^{\prime}, C-C^{\prime}$ ) with the Frontier Formation and associated rocks on the north side of the Uinta basin. Almost twice as many drill-hole logs as shown were used to corroborate correlations along the lines of sections $B-B^{\prime}$ and $C-C^{\prime}$. Few drill holes penetrate middle Cretaceous rocks in the deeper central part of the Uinta basin, and middle Cretaceous rocks are not exposed along the west side of the basin, except in the area southeast of the Farnham dome. Hence, detailed correlations could not be made across these parts of the Uinta basin.

The uniform thicknesses between marker beds (time slices) in most of the area indicate very uniform tectonic conditions during middle Cretaceous time. Immediately west of the Farnham dome, however, deposition and subsidence rates increase rapidly toward the axis of the mid-Cretaceous foredeep west of the Wasatch Plateau (pl. 1, section $B-B^{\prime}$, fig. 5).

The following description, in ascending order, of middle Cretaceous rocks along the south side of the Uinta basin is based both on outcrop information and interpretations of drill-hole logs. Relations of middle Cretaceous rocks on the east and northeast sides of the Uinta basin are discussed separately.

\section{Cedar Mountain Formation}

The Cedar Mountain Formation, named by Stokes (1944, 1952), is a widespread formation of Early and Late (?) Cretaceous age that covers much of the western and northwestern parts of the Colorado Plateau. East of the Colorado River and a line extending north-northeast across the Piceance basin, at least partially lithically and temporally equivalent rocks are called Burro Canyon Formation (Stokes, 1952; Craig, 1981). Throughout the area, the Cedar Mountain overlies the Morrison Formation, which has been considered Late Jurassic in age. Most investigators consider the contact to be disconformable (Stokes 1944; Mitchell, 1956; Quigley, 1959; Young, 1960; Peterson, 1988), but some think it is conformable (Craig and others, 1955, 1961; Craig, 1981). The conformability of the contact is difficult to ascertain paleontologically because of sparse faunal control, but because of the large time span between the ages commonly assigned to these two formations (fig. 3), a queried unconformity is shown as separating the formations. Some recently reported fission-track dates from the upper part of the Morrison suggest that the Morrison may range into Early Cretaceous time (Kowallis and Heaton, 1987). Addressing the latest interpretations of the age of the upper part of the Morrison is beyond the scope of this report; therefore, we show the Morrison as all Late Jurassic in age.

In most of the study area, the Cedar Mountain Formation is $200-300 \mathrm{ft}(60-90 \mathrm{~m})$ thick as interpreted from drill-hole logs (pl. 1 , sections $B-B^{\prime}, C-C^{\prime}$ ). West of the Farnham dome area, the Cedar Mountain thickens rapidly to more than $1,000 \mathrm{ft}(300 \mathrm{~m})$ (pl. 1, section $B-B^{\prime}$, fig. 5). On drill-hole logs on the west side of the area, the base of the Cedar Mountain is easily recognized by the basal conglomerate (Buckhorn Conglomerate Member) or sandstone bed overlying the predominantly shaly upper part of the Morrison Formation (pl. 1, section $\left.B-B^{\prime}\right)$. In some places, mostly to the east, the basal sandstone is not present (Young, 1960; Craig and others, 1961) or sandstone beds in the upper part of the Morrison make it difficult to pick the contact on drill-hole logs. Therefore, the contact as shown on the eastern cross 


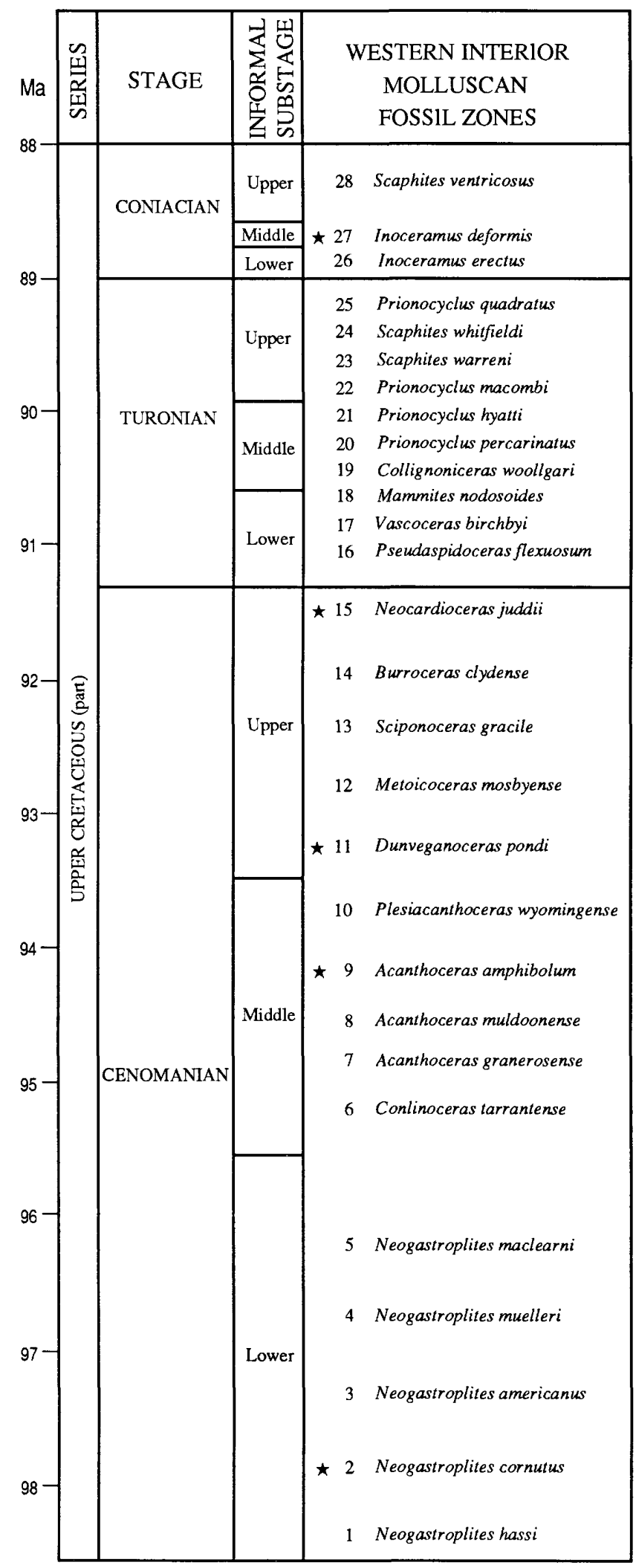

Figure 4. Cenomanian through Coniacian (lower Upper Cretaceous) U.S. Western Interior molluscan fossil zones. Stars indicate sequential location of rocks radiometrically dated by Obradovich and Cobban (1975) and by J.D. Obradovich (oral commun., 1989). section (pl. 1, section $C-C^{\prime}$ ) is queried. According to Young (1960), the Cedar Mountain Formation consists of a massive basal conglomerate or conglomeratic sandstone $0-30 \mathrm{ft}(0-9 \mathrm{~m})$ thick (called the Buckhorn Conglomerate Member (Stokes, 1944, 1952) on the west side of the area) overlain by $200-300 \mathrm{ft}(60-90 \mathrm{~m})$ of gray-green to purple (or variegated) mudstone containing scattered lenticular beds of sandstone. The mudstone is massive or poorly bedded and bentonitic and contains thin beds of nodular limestone and chert.

On the basis of rare or scattered plant fossils, nonmarine bivalves, ostracodes, and pollen collected from the middle or upper part of the formation, the Cedar Mountain Formation is considered Aptian and Albian in age (Stokes, 1952; Mitchell, 1956; Young, 1960; Tschudy and others, 1984). Tschudy and others (1984) reported a late Albian angiosperm pollen from 46 $\mathrm{ft}(14 \mathrm{~m})$ below the top of the Cedar Mountain at a locality $30 \mathrm{mi}(48 \mathrm{~km})$ south of Price. The lower part of the formation is not dated and may extend into the Neocomian. The Cedar Mountain Formation may range into the lower Cenomanian on the east and south sides of the Uinta basin inasmuch as the upper part seems to intertongue to the north with the Dakota Sandstone, which in turn grades into the Mowry Shale, now considered early Cenomanian in age, in the northern part of the Uinta basin (to be discussed). The upper part and possibly all of the Mowry Shale is now considered early Cenomanian in age (Cobban and Kennedy, 1989). Greater truncation to the south under an unconformity at the top of the Cedar Mountain Formation, however, may have cut out all or part of the lower Cenomanian part of the Cedar Mountain on the south side of the Uinta basin.

\section{Dakota Sandstone}

The Dakota Sandstone overlies the Cedar Mountain (or Burro Canyon) Formation in much of the Colorado Plateau. Regionally, the Dakota is a basal nonmarine paludal and fluvial unit that was deposited as a result of rising base level associated with the southward and westward transgression of the shoreline of the Western Interior sea. Coal and gray carbonaceous shale distinguishes the Dakota from the underlying Cedar Mountain Formation, which lacks coal and contains shale that is light green or pastel.

Young (1960) considered the Dakota (his Naturita Formation of the Dakota Group) as a coastal facies of the more inland Cedar Mountain Formation. Craig and others (1961) disagreed with Young's interpretation, claiming that the Dakota Sandstone is separated from the underlying Cedar Mountain by a regional unconformity. Our results support the interpretation of Craig and others, inasmuch as a regional unconformity recognized to the north can be traced southward to the top of the 


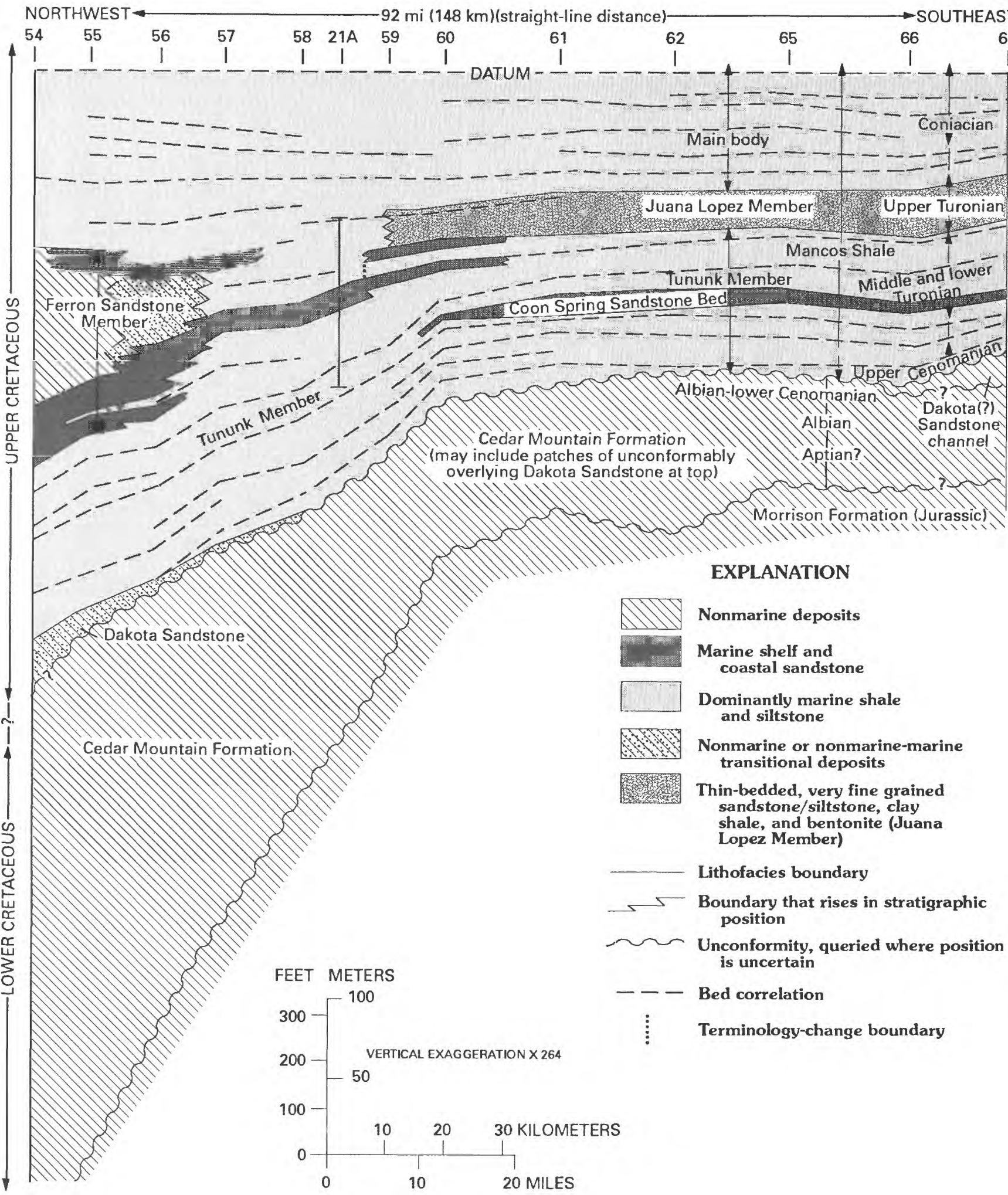

Figure 5. Stratigraphic correlation section along south side of Uinta basin. Line of section is shown in figure 2; control points are listed in table 1. See plate $1\left(B-B^{\prime}\right)$ for details of drill-hole logs. Drill hole 62 is not shown on plate 1. Datum is a marker bed in main body of the Mancos Shale. Correlations made in 1988. 


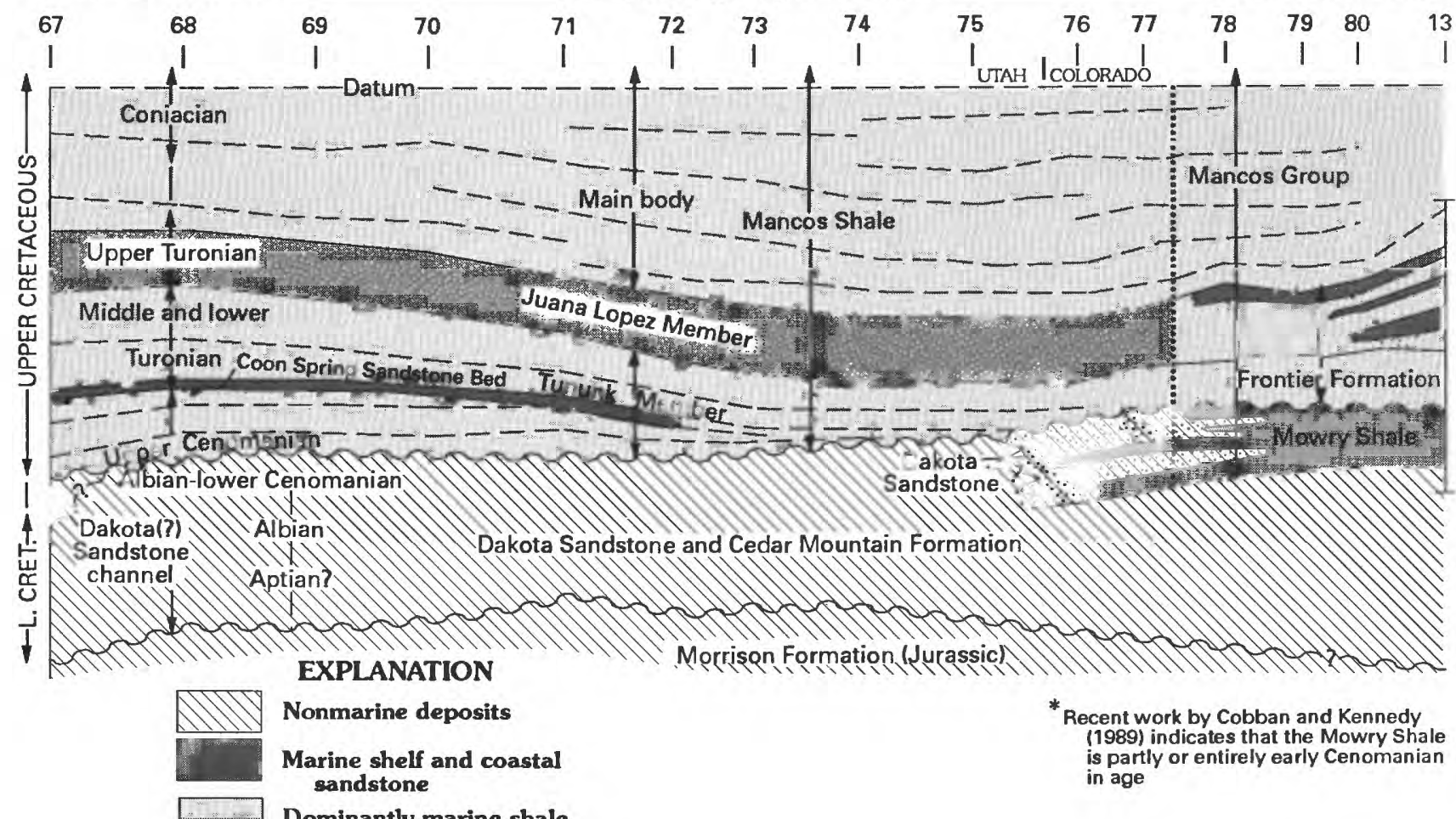

Dominantly marine shale and siltstone
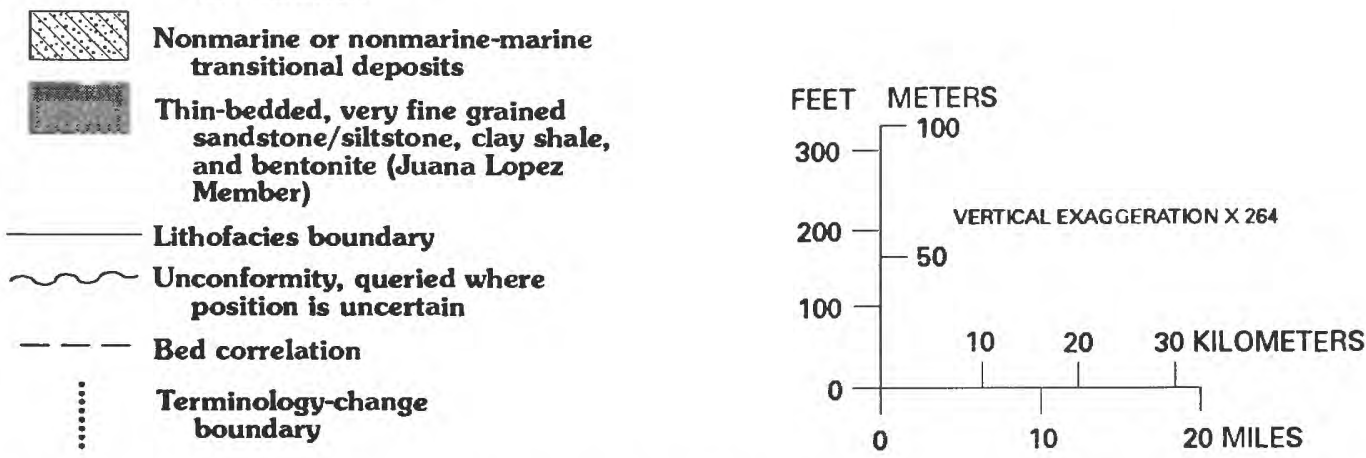

Figure 6. Stratigraphic correlation section along east side of Uinta basin. The apparent downlapping (rather than onlapping) pattern of the lower part of the Tununk Member is due to post-Juana Lopez differential subsidence along the line of section. Line of section is shown in figure 2; control points are listed in table 1. See plate $1\left(C-C^{\prime}\right)$ for details of drill-hole logs. Datum is a marker bed in main body of the Mancos Shale. Correlations made in 1988.

Cedar Mountain Formation. However, our correlations do indicate that the Dakota on the north side of the Uinta basin is different from the Dakota on the south side and that the older Dakota does indeed grade into the Cedar Mountain (to be discussed).

Although the Dakota on the south side of the Uinta basin is discussed in several reports describing the outcrop belt between the area southwest of Thompson and the Farnham dome (Dane, 1935; Fisher and others, 1960; Hintze and Stokes, 1964; Williams, 1964; Doelling, 1985; Witkind, 1988) (fig. 2), we think the Dakota is absent in much of this area. In many places, Mancos Shale with a thin lag of chert pebbles at its base rests directly on green mudstone of the Cedar Mountain Formation. Although there are few places where the base of the Mancos is exposed, the Dakota is mostly missing between the abandoned site of Valley City (sec. 27, T. 22 S., R. 19 E.), $10 \mathrm{mi}(16 \mathrm{~km})$ southwest of Thompson, and the east side of Woodside dome (control point 28), $20 \mathrm{mi}$ $(18 \mathrm{~km})$ northwest of Green River, Utah (fig. 2). Some discontinuous thin beds of Dakota Sandstone may be present in this area, or possibly what has been mapped as 
Dakota may actually be part of the Cedar Mountain Formation. Farther northwest toward the Farnham dome, generally less than $15 \mathrm{ft}(5 \mathrm{~m})$ of Dakota is locally present as indicated by the intercalated dark-gray or carbonaceous shale in sandstone beds. Because the Dakota is only present locally, it is included with the Cedar Mountain on the correlation sections (pl. 1, sections $\left.A-A^{\prime}, B-B^{\prime}\right)$.

We interpret the absence of the Dakota in the study area to be related to a regional unconformity, but due to lack of deposition rather than erosion. Where the Dakota is present, such as between the area south of Thompson and Grand Junction, we suggest that it onlaps the unconformity at the base of the Mancos Shale and above the Cedar Mountain Formation. A 75-ft (23 m) thick sandstone or conglomerate unit below the Mancos Shale in the Texaco Thompson Unit No. 1 well (control point 67 , pl. 1, sections $B-B^{\prime}, C-C^{\prime}$ ) is inferred as a Dakota channel fill cut into the Cedar Mountain.

In the subsurface west of the Farnham dome, we interpret the Dakota to be present either by grading into the basal part of the Mancos Shale or by depositional onlap (pl. 1, section $B-B^{\prime}$ ). Its presence in that area is indicated by coal and bivalve fossil fragments (presumably marine) in a core of the sandstone interval directly beneath the Mancos in a drill hole within $1 \mathrm{mi}$ $(1.6 \mathrm{~km})$ of control point 55 (pl. 1, section $\left.B-B^{\prime}\right)$. The Cedar Mountain Formation does not contain coal or marine fossils, thus our assignment of these rocks to the Dakota. The Dakota thickens to the west beneath the Wasatch Plateau and is present in outcrops on the west side of the Plateau, where it is known as the Sanpete Formation of late Cenomanian and early Turonian age (Fouch and others, 1983). Thin sandstone beds at the base of the Mancos Shale, such as near Mounds Reef (control point 23, pl. 1, section $A-A^{\prime}$ ), are inferred to be local sandstone deposits above the unconformity and are considered Dakota Sandstone.

The Dakota is present in the outcrop belt between the area south of Thompson and Grand Junction, where it is as thick as $120 \mathrm{ft}$ (37 m) (Young, 1960). It consists of channel and coastal sandstone, gray carbonaceous shale, and minor amounts of conglomerate and coal.

Because most or all of the Dakota Sandstone is nonmarine, reported age determinations are based either on nonmarine plant remains or on marine faunas in the intertonguing and overlying Mancos Shale. Fossil plants collected by Richardson (1909) from what was considered as Dakota Sandstone near Green River and

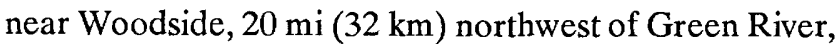
were assigned to the Cenomanian. Dane (1935) reported the late Cenomanian index fossil Pycnodonte newberryi (formerly called Gryphaea newberryi; Cobban, 1976) from the Mancos Shale directly above the Dakota northeast of Thompson near the Colorado State line.
Farther east in Colorado, Eicher (1965) identified foraminifers of the early middle Cenomanian Trochamminoides apricarius zonule from the lowermost part of the Mancos Shale near Loma, $15 \mathrm{mi}(24 \mathrm{~km})$ northwest of Grand Junction, and Fisher and other (1960) reported the early middle Cenomanian ammonite Calycoceras gilberti from the Dakota Sandstone near Delta, $30 \mathrm{mi}(48$ $\mathrm{km}$ ) southeast of Grand Junction. The Dakota Sandstone, where it is present on the south side of the Uinta basin, is most likely middle and late Cenomanian in age.

\section{Mancos Shale}

Only the lower $500-1,000 \mathrm{ft}(150-300 \mathrm{~m})$ of the thick, marine Mancos Shale is considered in this report. This part of the Mancos includes three formal members, the Tununk, Ferron Sandstone, and Juana Lopez Members, and the lower part of the main body of the Mancos. In addition, the Coon Spring Sandstone Bed is proposed for a sandstone bed in the middle of the Tununk Member. Some of the above units are not present throughout the entire area.

\section{Tununk Member}

The Tununk Member of the Mancos Shale was named for the marine shale between the Dakota Sandstone and the overlying Ferron Sandstone Member of the Mancos in the Henry Mountains region (Gilbert, 1877; Hunt and Miller, 1946) and the Castle Valley area (Lupton, 1916). In the outcrop belt on the south side of the Uinta basin, the Tununk has been mapped as far east as the Colorado State line (Hintze and Stokes, 1964). Across most of the outcrop belt, the Tununk underlies the resistant, cuesta-forming Juana Lopez Member. Drill-hole logs indicate that the Tununk ranges in thickness from about $400 \mathrm{ft}(120 \mathrm{~m})$ near the Farnham dome on the west to about $300 \mathrm{ft}(90 \mathrm{~m})$ near Thompson on the east.

The base of the Tununk marks a regional unconformity in most of the area, except east of the Thompson area where the Tununk conformably overlies the Dakota Sandstone, the unconformity being at the base of the Dakota. Where the Dakota is absent, the Tununk rests unconformably on the Cedar Mountain Formation. Although poorly exposed, in many places the contact is marked by the change from gray-green, bentonitic mudstone of the Cedar Mountain below to dark-gray shale of the Tununk above. Commonly, a pebble conglomerate lag a few inches thick is at the contact, such as in outcrops south (NW/4 sec. 2, T. $22 \mathrm{~S}$., R. 16 E.) and west (SE/4 sec. 35, T. 21 S., R. 14 E.) of 
Green River. In some areas, a sandstone bed as thick as $30 \mathrm{ft}(9 \mathrm{~m})$ separates the Tununk from green mudstone of the Cedar Mountain. This sandstone may be a basal transgressive unit, which is logically considered Dakota Sandstone, or it may be a fluvial sandstone lens in the Cedar Mountain Formation. The identity of the sandstone is difficult to determine on drill-hole logs, and the contact is more difficult to determine on logs where there is no sandstone. Hence, the basal contact is queried in several places on the subsurface correlation sections (pl. 1, sections $B-B^{\prime}, C-C^{\prime}$ ). The continuity of resistivity patterns in the marine shale of the Tununk versus the lack of continuity in the resistivity patterns in the nonmarine mudstone of the Cedar Mountain indicates, however, that the interpreted position of the contact is fairly close.

Drill-hole logs indicate that rock types and thicknesses of the various parts of the Tununk Member are fairly uniform across most of the south side of the Uinta basin, except for gradual thinning to the east. At the Grassy and Woodside dome surface sections (control points 27 and 28, pl. 1, sections $A-A^{\prime}, B-B^{\prime}$ ), however, the lower part of the Tununk is thinner than nearby downdip drill holes indicate. This thinning may indicate early growth of the San Rafael uplift. West of the Farnham dome, the Tununk thickens greatly and the upper part intertongues with the Ferron Sandstone Member (pl. 1, section $B-B^{\prime}$, fig. 5). For convenience in describing the lithology of the Tununk east of the Farnham dome, the Tununk is divided into three parts, which are the lower part, the Coon Spring Sandstone Bed, and the upper part.

\section{Lower Part of Tununk Member}

The lower part of the Tununk is about $100-200 \mathrm{ft}$ $(30-60 \mathrm{~m})$ thick, and at or near the surface it generally underlies an alluvial- or soil-covered flat. Based on outcrops and drill-hole logs, the lower part of the Tununk in most of the study area consists of, in ascending order, (1) 1-2 in. (2-5 cm) of chert-pebble conglomerate or sandy mudstone, (2) 20-30 ft (6-9 m) of dark-gray slightly calcareous clay shale containing at least three bentonite beds, one of which is $2 \mathrm{ft}(50 \mathrm{~cm})$ thick, and (3) $100-120 \mathrm{ft}(30-36 \mathrm{~m})$ of silty, dark-gray shale that grades upward to medium- to dark-gray, poorly bedded, bioturbated siltstone. The siltstone in turn grades upward into very fine grained sandstone of the Coon Spring Sandstone Bed. Units 1 and 2 and the lower part of 3 are well exposed $4 \mathrm{mi}(6 \mathrm{~km})$ south of Green River in NW/4 sec. 2, T. 22 S., R. 16 E. At the Farnham dome, sandy siltstone grading upward to siltstone overlies the Cedar Mountain Formation (control point 21B, pl. 1, section $\left.A-A^{\prime}\right)$. The early Turonian megafossil Mytiloides cf. $M$. mytiloides collected from $15 \mathrm{ft}(4 \mathrm{~m})$ above the contact and the lithology indicate that the base of the Tununk at the Farnham dome is younger than the base to the southeast, which contains late Cenomanian fossils. This relation suggests early structural growth of the Farnham dome.

Pycnodonte newberryi (Stanton), an oyster of late Cenomanian age, was collected at the base of the Tununk south of Green River and west of Green River (control point 30 , pl. 1, section $A-A^{\prime}$ ), where these fossils are locally abundant. Young (1960) reported this fossil in the lower part of the Tununk at several places along the outcrop belt, and Fisher and others (1960) reported it from the base of the Mancos Shale at a few localities between the outcrop belt southeast of Thompson and the Colorado State line. South of the study area on the west side of the San Rafael uplift $10 \mathrm{mi}(16 \mathrm{~km})$ east of Emery, Eaton and others (1990) reported specimens of $P$. newberryi at the base of the Tununk but interpreted them to have been reworked from older rocks and redeposited in late early Turonian strata above an unconformity. This same interpretation may apply in the study area, but because of the locally great abundance of $P$. newberryi, we think that the fossils are weathered out of near-basal Tununk strata. At Cache Creek graben in Arches National Park, $19 \mathrm{mi}(30 \mathrm{~km})$ southeast of Thompson, $P$. newberryi is present as weathered-out specimens about $15 \mathrm{ft}(4 \mathrm{~m})$ above a thin Dakota Sandstone.

The early middle Turonian ammonite, Collignoniceras woollgari, was collected from the overlying Coon Spring Sandstone Bed. Thus, the lower part of the Tununk Member ranges in age from late Cenomanian to early middle Turonian.

Besides the early Turonian megafossil mentioned, no other early Turonian megafossils on the south side of the Uinta basin have been reported. This part of the Tununk is generally covered or poorly exposed. Lessard (1973), however, reported foraminifers of Greenhorn age (late Cenomanian-early Turonian) from the Tununk in the study area. The Greenhorn in the study area would include equivalents of the Bridge Creek Limestone Member of the Greenhorn Limestone, but at this western location in the seaway (fig. 1), limestone or even very calcareous shale is absent.

\section{Coon Spring Sandstone Bed of the Tununk Member}

The Coon Spring Sandstone Bed of the Tununk Member of the Mancos Shale is here named for a sandstone bed as thick as $75 \mathrm{ft}(23 \mathrm{~m})$ in the middle of the Tununk Member. This bed extends eastward from about $14 \mathrm{mi}(23 \mathrm{~km})$ southeast of the Farnham dome almost to Grand Junction (fig. 2). Interpretation of drill-hole logs west and southwest of the Farnham dome indicates that the Coon Spring Bed grades into siltstone. No attempt was made to trace it farther east to the Piceance basin. It is covered or very poorly exposed along the outcrop belt from a few miles southeast of Green River to a few miles 
Table 3. Type section of the Coon Spring Sandstone Bed of the Tununk Member of the Mancos Shale [SE1/4 sec. 24, T. 17 S., R. 13 E., Emery County, Utah. Measured up gully in south-facing cliff by C.M. Molenaar]

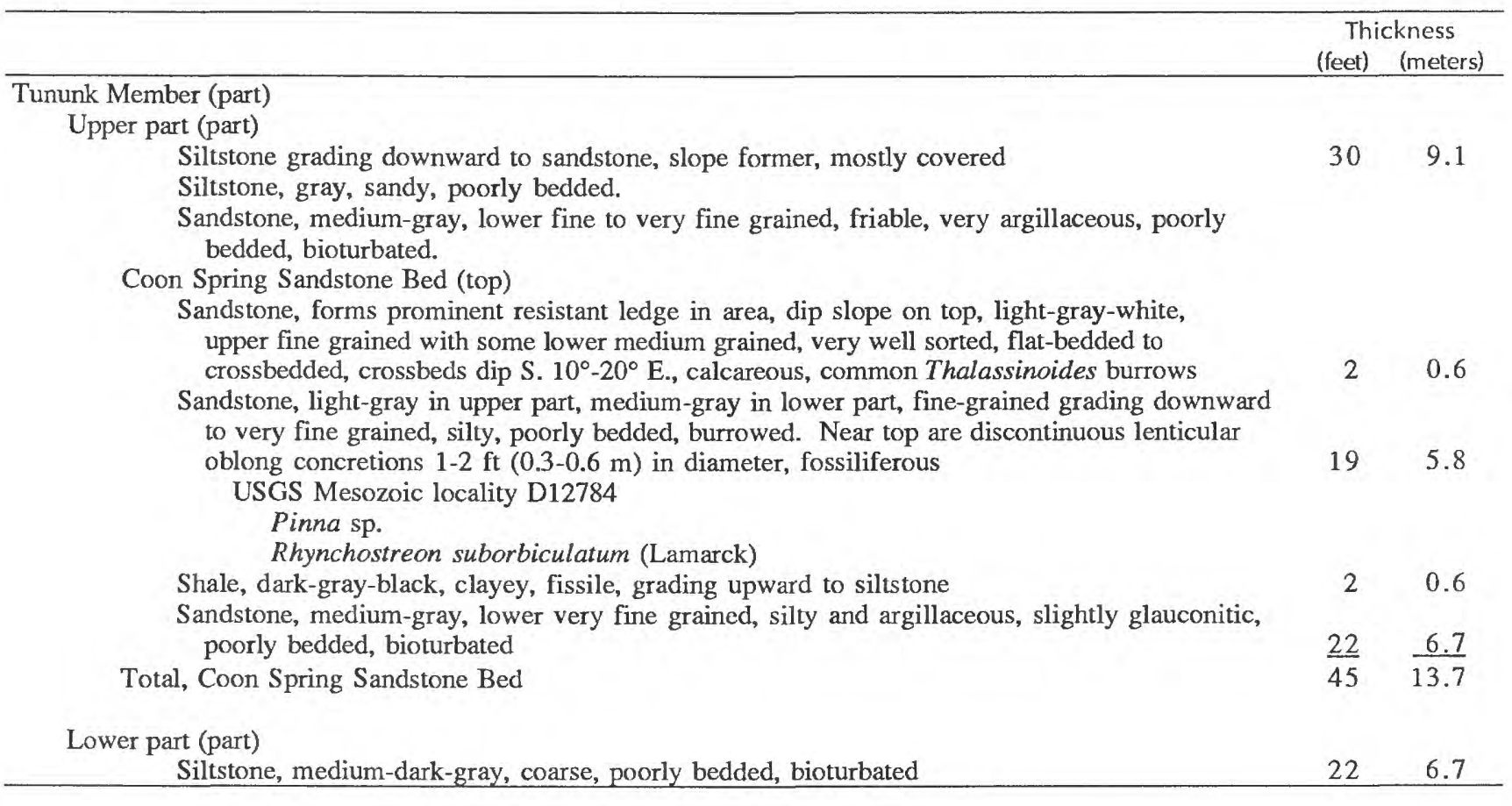

west of the Colorado State line, where it is well exposed; the sandstone may have graded into siltstone in much of the intervening area or the sandstone is friable. It is not present in the Cache Creek graben in Arches National Park, $19 \mathrm{mi}(30 \mathrm{~km})$ southeast of Thompson. A relatively resistant unit consisting of interbedded, very fine grained sandstone and siltstone that occurs in the middle of the Tununk Member in the Hanksville and Caineville areas, $55-65 \mathrm{mi}(88-105 \mathrm{~km})$ southwest of Green River, is probably equivalent to the Coon Spring Sandstone Bed (M.A. Kirschbaum, U.S. Geological Survey, oral commun., 1989).

The Coon Spring Sandstone Bed is named after Coon Spring in the NE/4 sec. 3, T. 17 S., R. 13 E. (near control point 26, pl. 1, section $A-A^{\prime}$ ), and the type section is about $4 \mathrm{mi}(6.4 \mathrm{~km})$ to the southeast near the center of the SE/4 sec. 24, T. 17 S., R. 13 E. (control point 27). The unit is best exposed in a small gully in a south-facing cliff, where the unit is $45 \mathrm{ft}(14 \mathrm{~m})$ thick (fig. 7). A detailed description is given in table 3. Most of the unit consists of medium-gray, lower very fine grained, bioturbated, silty sandstone that in the upper part grades into light-gray, less silty, fine-grained sandstone. The unit is capped by $2-3 \mathrm{ft}(0.6-0.9 \mathrm{~m})$ of well-sorted, upper fine- to mediumgrained, resistant ledge-forming sandstone. Because the base of the Coon Spring Bed is transitional downward from very fine grained silty sandstone into structureless (or massive-weathering), bioturbated, coarse siltstone, the placement of the base of the sandstone bed can be arbitrary, especially on drill-hole logs; the SP curve being depressed owing to the silt or clay content of much of the bed. In the subsurface northeast of Thompson, some petroleum geologists have referred to this bed as the "Dakota silt" (Munger, 1965). Because the intermixed silt and clay in the sandstone bed cause an attenuated or suppressed SP log response on drill-hole logs, the position of the base of the bed as shown on plate 1 (sections $B-B^{\prime}, C-C^{\prime}$ ) may be too high and the thickness of the bed may be greater than that shown. The sandstone bed is overlain by a transition zone about $25 \mathrm{ft}$ $(8 \mathrm{~m})$ thick consisting of very fine grained silty sand or friable sandstone in the lower part that grades upward to siltstone, all of which weather similar to shale.

In addition to the type section (control point 27, pl. 1 , section $A-A^{\prime}$ ), the Coon Spring Sandstone Bed also is well exposed on the east side of the Woodside dome (control point 28), along Cottonwood Wash (control point 29), and along highway I-70 west of Green River (control point 30 , pl. 1, section $A-A^{\prime}$ ). The bed seems to be thickest (about $75 \mathrm{ft}, 23 \mathrm{~m}$ ) at the latter two locations, but, as mentioned, the gradation from coarse siltstone to very fine argillaceous silty sandstone makes placement of the basal contact arbitrary. The uppermost thin, resistant, medium-grained sandstone is probably the result of winnowing out of the finer grains by wave and current action. This part of the bed contains Thalassinoides and Ophiomorpha burrows and is commonly crossbedded; the crossbed dip directions are generally to the south and 


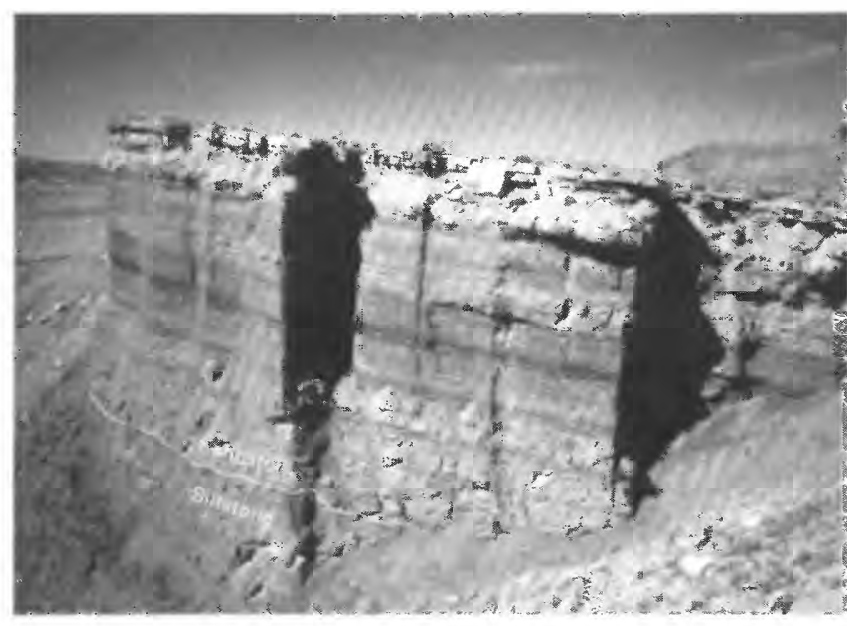

Figure 7. Type section of the Coon Spring Sandstone Bed of the Tununk Member of the Mancos Shale at control point 27 (Grassy surface section, fig. 2, table 1). View looking north.

southeast, but opposed directions are also present (Cotter, 1975). Except for the top part that is cemented by calcite, most of the Coon Spring Bed is friable in exposures and commonly is slope forming. In some places, however, thin, resistant beds $1-2 \mathrm{ft}(<1 \mathrm{~m})$ thick also are present within the Coon Spring, such as at control point 29 (pl. 1, section $\left.A-A^{\prime}\right)$. These beds are less silty and probably formed by removal of clay and silt from the sand by wave or current action. Three thin ledgeforming beds are present about one-half mile north of control point 28 (pl. 1). Cotter (1975), in his study of the Ferron Sandstone Member, referred to the Coon Spring Bed at this location as the Woodside unit.

Abundant, large (as much as $5 \mathrm{ft}(1.5 \mathrm{~m})$ in diameter), brown-weathering sandstone concretions are prominent in the upper part of the Coon Spring Sandstone Bed at many locations, such as near Green River. The concretions contain the large bivalves Rhynchostreon and Pinna and, in a few places, the ammonite Collignoniceras woollgari, an early middle Turonian guide fossil. This ammonite species was also collected from the lower part of the Coon Spring Bed, thus affixing an early middle Turonian age to the bed. Inferences about depositional conditions and the extent of the Coon Spring Bed are discussed later.

\section{Upper Part of Tununk Member}

The upper part of the Tununk is about $130 \mathrm{ft}$ (40 m) thick and forms a slope beneath the resistant Ferron Sandstone Member on the west or the cuesta-forming Juana Lopez Member on the east (pl. 1, section $A-A^{\prime}$ ). Although the slope commonly is sheathed by a mantle of weathered rock, the lithology of the unit can be ascertained by shallow digging. Above the Coon Spring
Sandstone Bed, as mentioned, the lower 10-25 ft (3-8 m) of the upper part is a fining-upward sequence of argillaceous, very fine grained, friable sandstone grading upward to silty shale. A resistant, blue-gray, sandy mudstone bed, $1 \mathrm{ft}(25 \mathrm{~cm})$ or less thick, is about $30 \mathrm{ft}(9 \mathrm{~m})$ above the top of the Coon Spring Sandstone Bed or equivalents in areas northwest of the Woodside dome (control point 28, pl. 1, section $A-A^{\prime}$ ). This thin resistant bed contains very fine to fine sand grains in a muddy, silty matrix and is much more indurated than adjacent beds. Burrowing has obscured primary bedding features. This characteristic marker bed is present wherever this part of the section is exposed northwest of the Woodside dome area (control point 28, pl. 1 , section $A-A^{\prime}$ ). A bentonite bed about $3 \mathrm{ft}(1 \mathrm{~m})$ thick overlies the resistant bed at the Farnham dome but was not noted at the Grassy or Woodside dome sections (control points 27, 28, pl. 1, section $A-A^{\prime}$ ). At these locations, the bentonite or ash is probably intermixed with the silty mudstone inasmuch as resistivity logs indicate a bentonitic zone in this interval (pl. 1, section $B-B^{\prime}$ ).

The remaining part of the upper part of the Tununk consists of silty, noncalcareous, bentonitic shale that grades upward into siltstone. The siltstone at the top of the Tununk is structureless, bioturbated, noncalcareous, and spheroidal weathering (fig. 8) as it grades into sandstone of the Ferron Sandstone Member on the northwest (pl. 1, section $A-A^{\prime}$ ). Locally, as at control point 29 (pl. 1, section $A-A^{\prime}$ ), the uppermost part is silty, very fine grained sandstone. Where exposures are good, as at control point 28 (pl. 1, section $A-A^{\prime}$ ), two buildups of sandy siltstone are present; these are finer grained, offshore equivalents of two Ferron sandstone beds that are present to the northwest, as at control points $22-25$ (pl. 1, section $A-A^{\prime}$ ).

The late middle Turonian guide fossil, Prionocyclus hyatti, was collected about $25 \mathrm{mi}(40 \mathrm{~km})$ southwest of the Farnham dome from the thin, resistant, blue-gray, sandy mudstone bed near the base of the upper part of the Tununk. Fossils of the same age are in the overlying or laterally equivalent Ferron Sandstone Member; thus, the upper part of the Tununk is mostly, if not completely, of late middle Turonian age. The total Tununk Member ranges in age from late Cenomanian to late middle Turonian.

\section{Ferron Sandstone Member}

The Ferron Sandstone Member of the Mancos Shale was named by Lupton (1916) for exposures near the town of Ferron, $40 \mathrm{mi}(64 \mathrm{~km})$ southwest of Price (fig. 2). On the west side of the San Rafael uplift, it crops out from about $78 \mathrm{mi}(125 \mathrm{~km})$ southwest of Price north to the Farnham dome and then extends southeast about $15 \mathrm{mi}(24 \mathrm{~km})$ on the north plunge of the San Rafael 


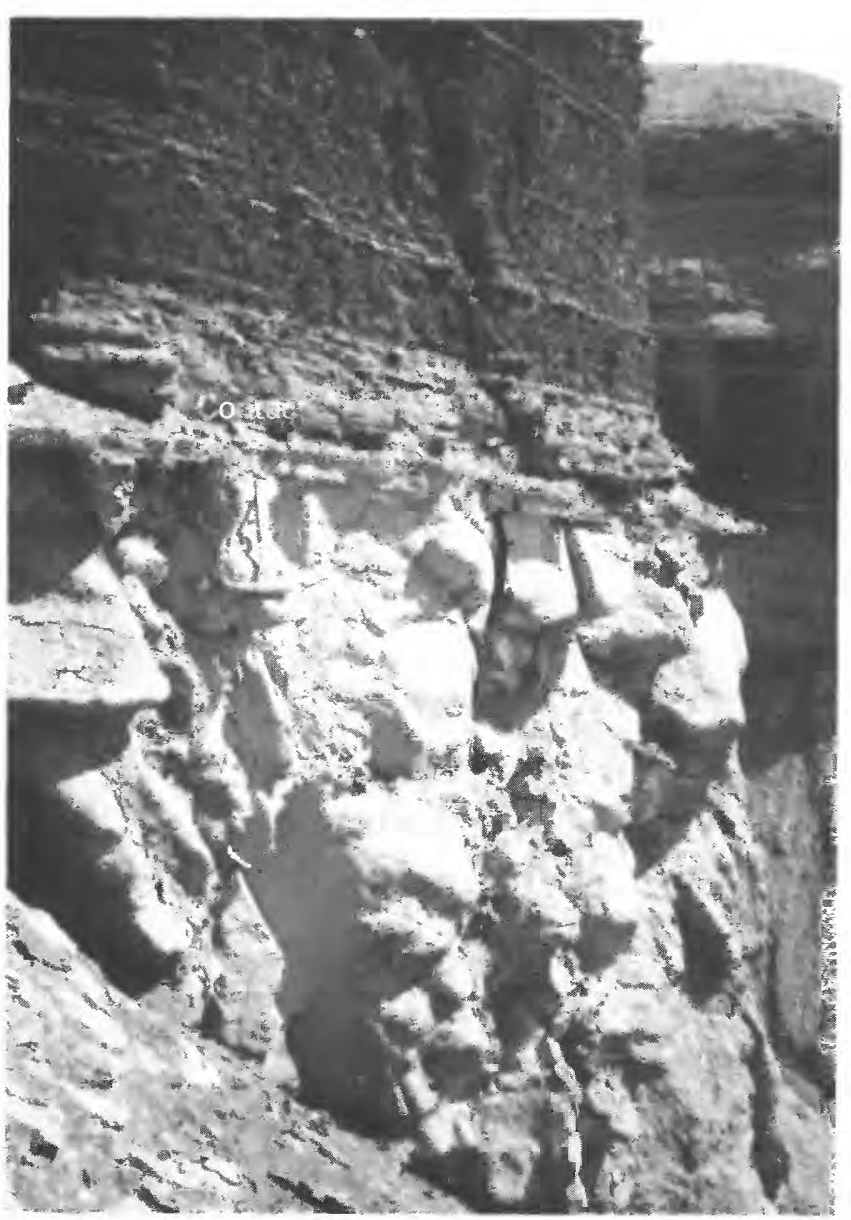

Figure 8. Contact (at top of handle of geology pick) of structureless, spheroidically weathering siltstone of the Tununk and overlying Juana Lopez Members of the Mancos Shale at control point 27 (Grassy surface section, fig. 2, table 1).

uplift. Existing geologic maps (Hintze and Stokes, 1964) show it extending as far east as the Colorado State line, but our results indicate that it grades into siltstone about $15 \mathrm{mi}(24 \mathrm{~km})$ southeast of the Farnham dome (pl. 1, section $\left.A-A^{\prime}\right)$.

The Ferron is as thick as $400 \mathrm{ft}(122 \mathrm{~m})$ near Ferron (no specific type section was designated by Lupton, 1916) but in outcrops in the study area is $0-90 \mathrm{ft}$ (0-27 m) thick (pl. 1, section $\left.A-A^{\prime}\right)$. Most of the upper half of the Ferron near Ferron grades northeastward toward the Farnham dome into the Mancos Shale; only the lower part correlates with the Ferron at the Farnham dome (fig. 9) (Ryer and McPhillips, 1983; Cotter, 1975). It thickens to the west in the subsurface by intertonguing with the Mancos Shale at the top and base and by depositional thickening to almost $500 \mathrm{ft}(152 \mathrm{~m})$ at the Clear Creek gas field on the Wasatch Plateau (pl. 1, section $\left.B-B^{\prime}\right)$. The Ferron gradationally overlies the Tununk Member and is overlain by the main body of the Mancos Shale west of the Farnham dome (or Blue Gate
Member of the Mancos on the west side of the San Rafael uplift) and by the Juana Lopez Member of the Mancos Shale east and southeast of the Farnham dome (pl. 1 , sections $A-A^{\prime}, B-B^{\prime}$ ).

On the west flank of the Farnham dome, the Ferron Member essentially consists of one sandstone unit about $50 \mathrm{ft}(15 \mathrm{~m})$ thick. The sandstone is mostly very fine grained, partly bioturbated, hummocky crossbedded in the lower half, and fossiliferous and contains large, brown-weathering concretions near its top. Cotter (1975) called this sandstone bed the Farnham unit. The bed thins to about $10 \mathrm{ft}(3 \mathrm{~m})$ on the southeast side of the Farnham dome and then thickens somewhat as it grades into siltstone to the southeast (pl. 1, section $A-A^{\prime}$ ). An upper sandstone unit, separated from the lower sandstone by $25-30 \mathrm{ft}(8-9 \mathrm{~m})$ of silty shale, is developed on the southeast side of the Farnham dome. It grades into siltstone or shale within a few miles to the north, thickens to about $35 \mathrm{ft}(11 \mathrm{~m})$ at Mounds Reef to the southeast, and then thins farther southeast as it grades into siltstone in about the same area as the termination of the lower sandstone bed (pl. 1, section $A-A^{\prime}$ ). The upper sandstone bed is fine to very fine grained, thick bedded to massive, and generally burrowed or bioturbated. Correlations between the east and west sides of the Farnham dome are complicated by (1) the abrupt termination of the upper sandstone bed of the Ferron on the east side, (2) the lack on the west side of the dome of the distinctive Juana Lopez lithology (to be discussed) that overlies the Ferron on the east side, and (3) marked depositional thickening to the west across the faulted structure. In addition, the stratigraphy may be complicated by sediments that came from separate deltas to the northwest and southwest.

Megafossils, such as Prionocyclus hyatti and Inoceramus howelli, collected from the two Ferron sandstone beds southeast of the Farnham dome indicate a late middle Turonian age. Subsurface correlations to the west of the Farnham dome toward the Clear Creek gas field show that, by intertonguing with the Mancos Shale, the upper part of the Ferron at Clear Creek is probably late Turonian in age (pl. 1 , section $B-B^{\prime}$ ). Similarly, correlations to the southwest indicate that the upper, coal-bearing part of the Ferron near Ferron is late Turonian in age (fig. 9) (Ryer and McPhillips, 1983).

\section{Juana Lopez Member}

The Juana Lopez Member of the Mancos Shale is widespread throughout much of the central Colorado Plateau. It was named by Rankin (1944) for $10 \mathrm{ft}(3 \mathrm{~m})$ of very calcareous sandstone about $18 \mathrm{mi}(29 \mathrm{~km})$ southwest of Santa Fe, New Mexico. Subsequent work by Hook and Cobban (1980) amended the total thickness of the Juana Lopez at this location to $106 \mathrm{ft}(32 \mathrm{~m})$. The 

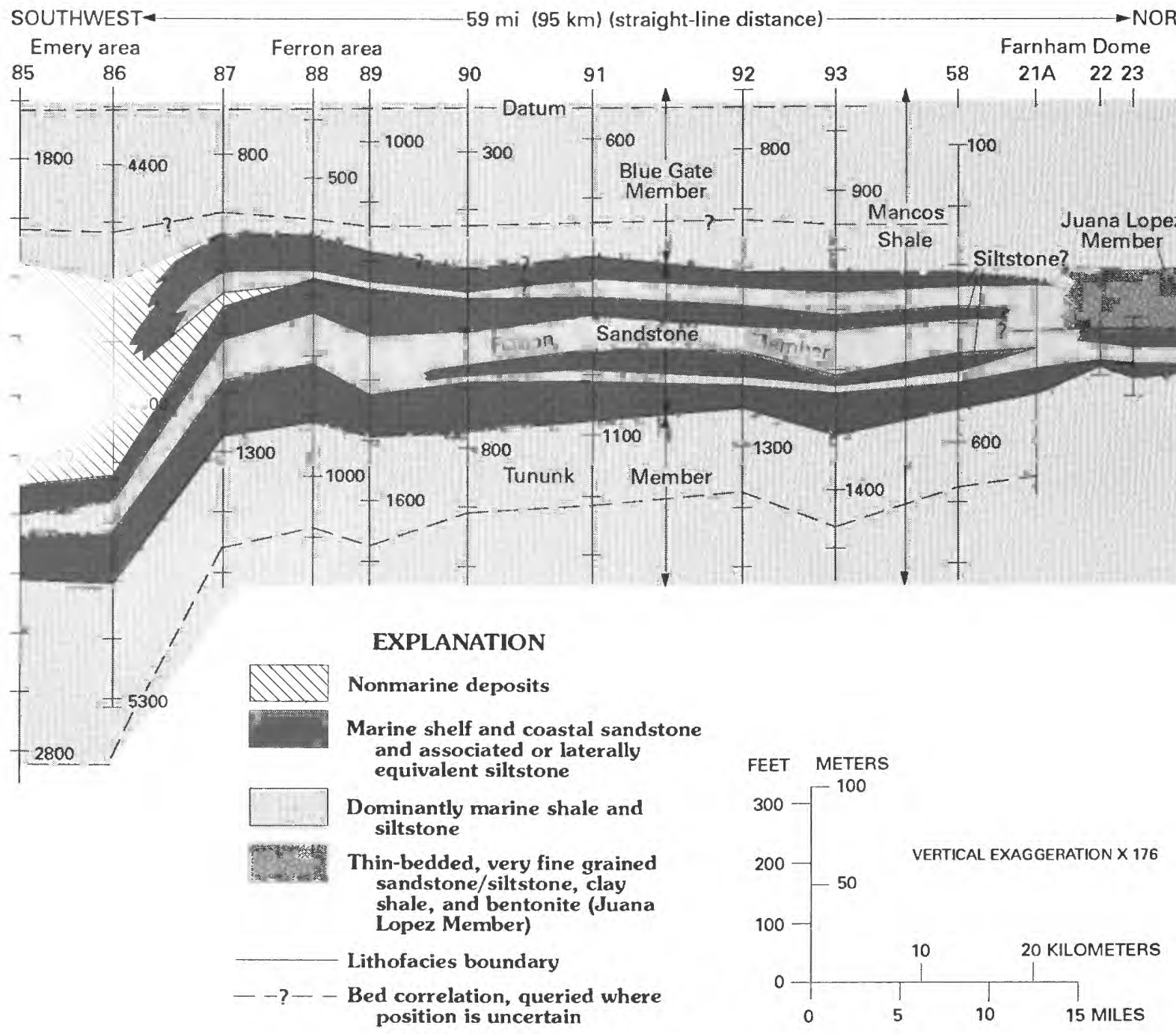

Figure 9. Stratigraphic correlation section showing relations of the Ferron Sandstone Member of the Mancos Shale near Ferron and the Ferron Sandstone and Juana Lopez Members of the Mancos Shale near the Farnham dome. Well depths are in feet below kelly bushing. Line of section is shown in figure 2; control points are listed in table 1. Datum is a marker bed in the main body of the Mancos Shale. Correlations made in 1989.

Juana Lopez is best known, however, in the San Juan basin of northwestern New Mexico, where it is a good marker unit in both the surface and subsurface (Bozanic, 1955). A reference section on the southeast side of the San Juan basin is $107 \mathrm{ft}$ (37 m) thick (Dane and others, 1966). Juana Lopez terminology also has been used in southeastern Colorado and northeastern New Mexico (Scott, 1964; Kauffman and others, 1969).

The Juana Lopez Member is 80-100 ft (24-30 m) thick on the south side of the Uinta basin; its basal contact is sharp with the underlying Ferron Sandstone Member, where the Ferron is present southeast of the Farnham dome, and with the Tununk Member farther southeast (pl. 1, section $A-A^{\prime}$ ). This contact marks a marine flooding surface; that is, an abrupt increase in water depth. On the west side of the Farnham dome, the distinctive Juana Lopez lithology has graded to uniform, dark-gray, silty shale of the main body of Mancos Shale. The Juana Lopez forms a prominent cuesta along much of the outcrop belt (figs. 10, 11); as mentioned earlier, geologic maps incorrectly show this as the Ferron Sandstone Member (Dane, 1935; Hintze and Stokes, 1964; Williams, 1964; Doelling, 1985; Witkind, 1988).

In most places along the outcrop belt, the lower $10-20 \mathrm{ft}(3-6 \mathrm{~m})$ of the Juana Lopez Member consists of dark-gray or black, noncalcareous, fissile clay shale that contrasts markedly with the structureless bioturbated siltstone of the Tununk Member (fig. 8). On drill-hole resistivity logs the clay shale has much lower resistivity as contrasted with the underlying siltstone (pl. 1, sections 


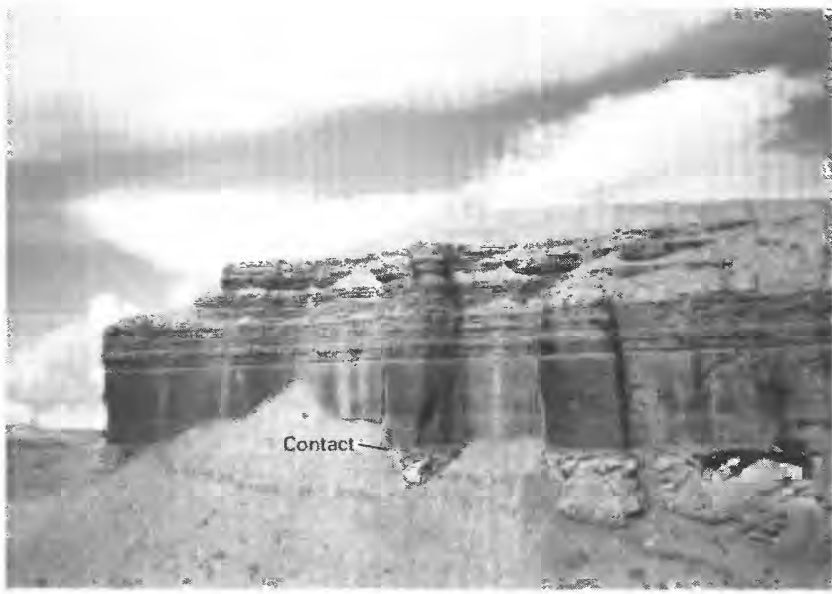

Figure 10. Cliff-forming Juana Lopez Member of the Mancos Shale overlying siltstone of the Tununk Member of the Mancos Shale (at base of cliff; see fig. 8 for closeup view). Vertical cliff on far left profile is about $30 \mathrm{ft}(9 \mathrm{~m})$. Thickness of exposed Juana Lopez to top of rubble-covered ridge is about $65 \mathrm{ft}(20 \mathrm{~m})$. View looking west.

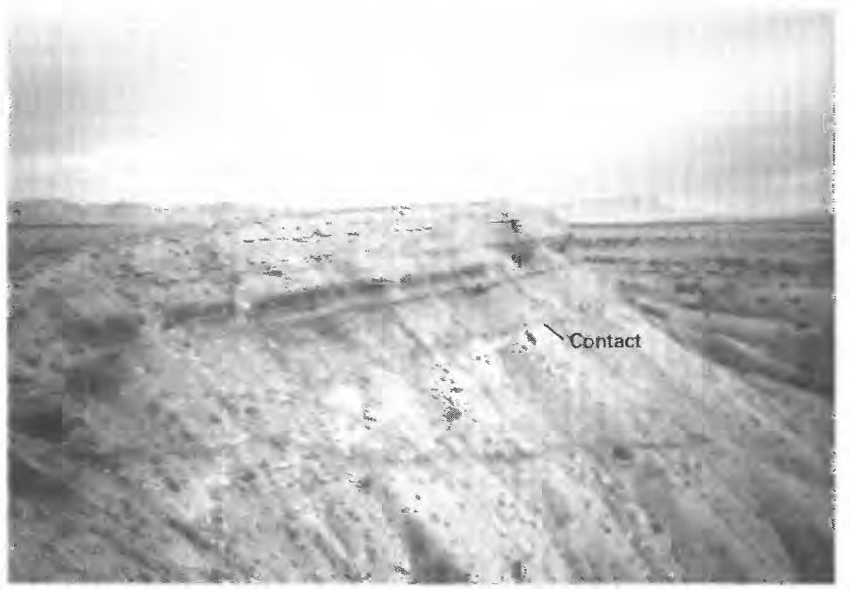

Figure 11. Cuesta-forming Juana Lopez Member of the Mancos Shale overlying the Ferron Sandstone Member of the Mancos Shale (light-colored bed) at control point 25 (North Cedar surface section, fig. 2, table 1). View looking southeast.

$\left.B-B^{\prime}, C-C^{\prime}\right)$. In some places, such as control points 26 and 28 (pl. 1, section $A-A^{\prime}$ ), the base of the Juana Lopez consists of $5-10 \mathrm{ft}(1.5-3 \mathrm{~m})$ of thinly interbedded clay shale and very fine grained sandstone or coarse siltstone. In other places, such as at Cottonwood Wash (control point 29, pl. 1, section $A-A^{\prime}$ ), the base consists of $3-4 \mathrm{ft}$ (1 $\mathrm{m})$ of fine- to medium-grained, slightly pebbly, mediumscale crossbedded sandstone (fig. 12). In a few places between Green River and the area south of Thompson, dark-gray or black chert pebbles as much as $1 \mathrm{in} .(2.5 \mathrm{~cm})$ in diameter were found at the base of the Juana Lopez.
These basal units are considered to be submarine transgressive lag(?) deposits associated with a relative sea-level rise and are overlain by the aforementioned fissile clay shale.

The remainder and major part of the Juana Lopez is dominantly thinly interbedded, dark-gray, noncalcareous clay shale and ripple-bedded, generally calcareous, very fine grained sandstone or coarse siltstone (fig. 13). Where exposures are good, thin beds of bentonite are visible within the member (fig. 10). In most places, this interbedded sequence weathers to rubble-covered hills or ridges in which only thin slabs of the very fine grained sandstone-coarse siltstone are apparent. The grain size of the sandstone/siltstone interbeds decreases slightly from very fine grained sandstone near the Farnham dome on the northwest to very fine grained sandstone and coarse siltstone near Green River on the southeast. The very fine grained sandstone/coarse siltstone beds are light gray and weather brown to olive brown. They range in thickness from less than an inch to a few inches. Contacts with underlying and overlying clay shale beds are sharp, and scour and prod marks are present on the base of a few beds. Ripple crossbedding or small-scale crossbedding is prevalent; crossbed dips are generally to the south and southeast. Starved ripple stratification also is present.

Calcarenite is a common constituent of the Juana Lopez at more distal or easterly locations, for example, the east side of the San Juan basin (Dane and others, 1966) and southeastern Colorado (Scott, 1964; Kauffman, 1977). Thin calcarenite beds are present in minor amounts in some of the sections southeast of Grassy Trail (control point 24, fig. 2). These distinctive beds are probably the result of fragmentation of mollusk shells by fish such as rays and sharks.

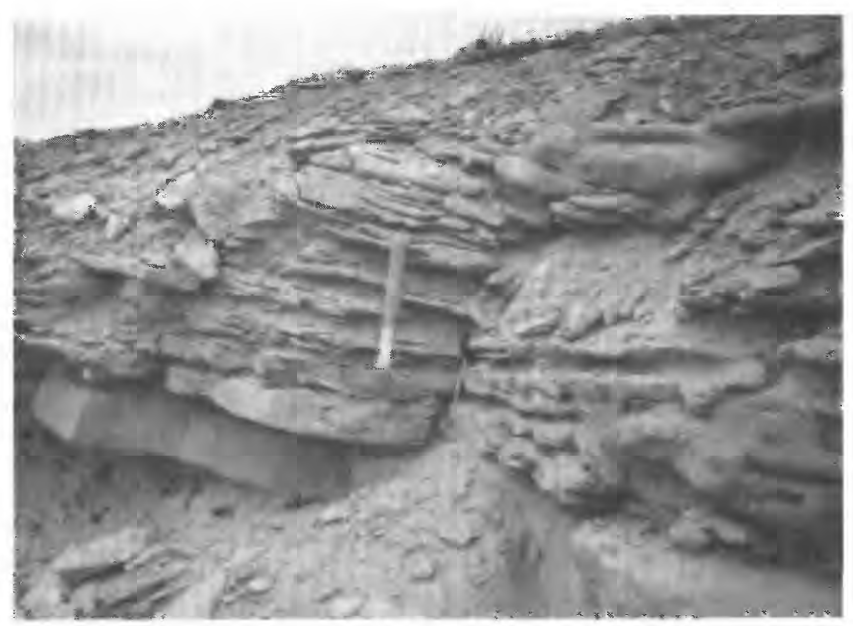

Figure 12. Basal transgressive sandstone of the Juana Lopez Member of the Mancos Shale near control point 29 (Cottonwood Wash surface section, fig. 2, table 1). Geology hammer shown for scale. 

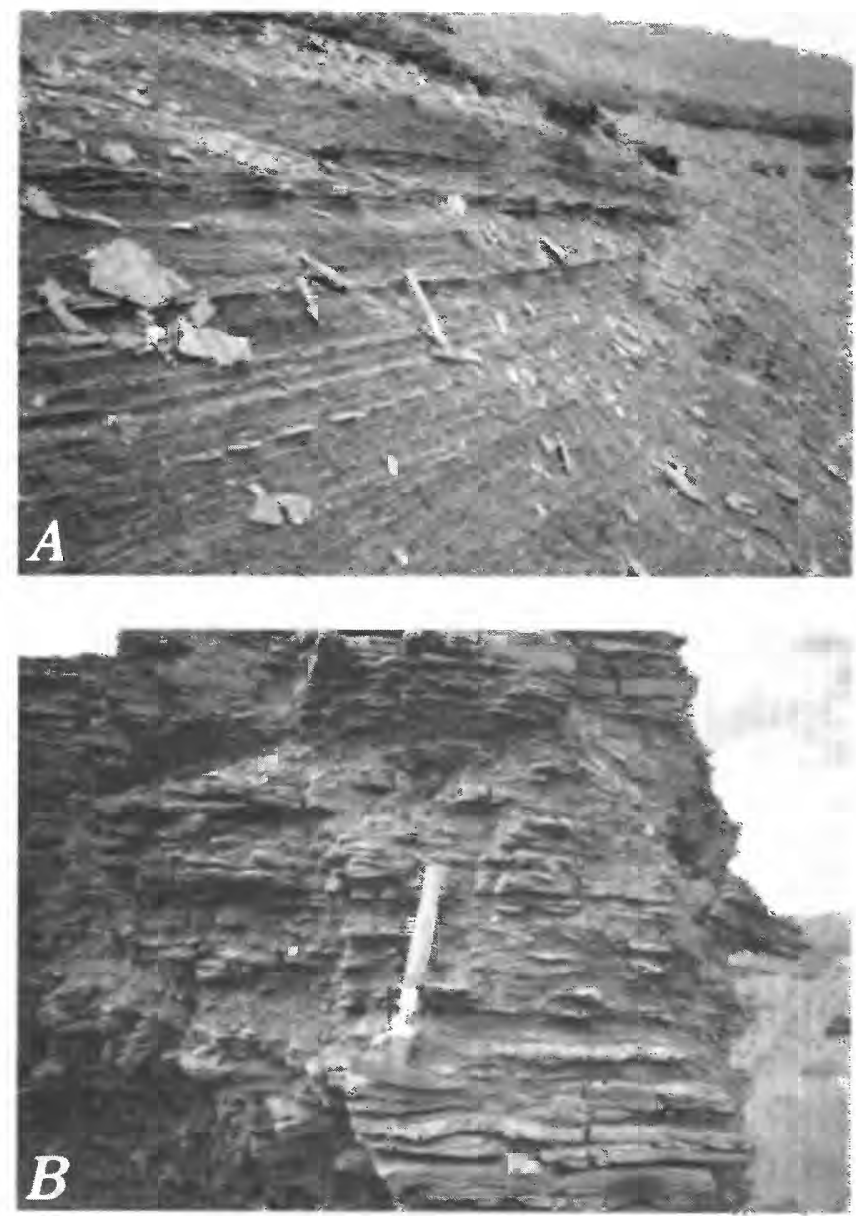

Figure 13. Interbedded, thinly ripple-bedded siltstone and very fine grained sandstone and clay shale of the Juana Lopez Member of the Mancos Shale. Geology hammer shown for scale. A, Lower part at control point 29 (Cottonwood Wash, fig. 2, table 1). B, Middle part at control point 27 (Grassy surface section).

The top of the Juana Lopez Member is very poorly exposed; it generally weathers to form an eroded, rubblecovered, shallow dip slope, so most measured surface sections are incomplete (pl. 1, section $A-A^{\prime}$ ). The total thickness is best measured on drill-hole logs (pl. 1, sections $B-B^{\prime}, C-C^{\prime}$ ).

The thin, medium-grained, crossbedded, pebbly sandstone bed and pebble zone that are present at the base of the Juana Lopez in a few areas, such as control point 29 (pl. 1, section $A-A^{\prime}$ ), are considered submarine transgressive lag(?) deposits associated with a relative sea-level rise (a marine flooding surface). They may represent high-energy deposition in offshore waters that occurred when sediment sources from distant deltas or shorelines were cut off by relatively rising sea level. The coarser grains may be the result of reworking and concentrating coarser material from the underlying Ferron or Tununk Members, but this interpretation is difficult to accept because textures that coarse were not observed in the Ferron (pl. 1, section $A-A^{\prime}$ ). It is significant to note, however, that at control point 29 (pl. 1 , section $A-A^{\prime}$ ), where the medium-grained pebbly sandstone is present at the base of the Juana Lopez, the underlying Tununk is sandier than at other locations. Perhaps the pebbly sandstone is a lag deposit resulting from reworking of the underlying Tununk. These coarse deposits may also have been derived from a delta front to the north or northwest. On the south side of the Uinta Mountains, Molenaar and Wilson (1990) reported channel sandstones cutting into shoreface sandstones that formed just prior to the relative sea-level rise in that area. These channel sandstones could have provided the coarser clastic material that was spread seaward to the south and southeast during a low stand of relative sea level.

The depositional mode of the rest of the Juana Lopez Member is somewhat enigmatic. The fissile clay shale and discrete bentonite beds were obviously deposited in a very quiet, probably relatively deep water, low-energy environment; however, the interbedded, ripple-bedded, very fine grained fossiliferous sandstone/ coarse siltstone indicates a higher energy environment (fig. 13). The sharp basal contacts, bottom scour or prod marks, and small-scale crossbedding suggest that these thin, very fine grained sandstone/siltstone beds may be the result of periodic storm currents. Current directions determined from observed crossbed dips indicate that the source of the sandstone and siltstone was to the north or northwest, probably the Vernal delta of the Frontier Formation.

The Juana Lopez is quite fossiliferous, although the northwestern outcrops are less so. Fossils characteristic of the Juana Lopez throughout its extent include the oyster Lopha lugubris, the bivalves Inoceramus dimidius and I. perplexus, and the ammonites Prionocyclus macombi, $P$. wyomingensis, and two or three species of Scaphites. These fossils indicate a late Turonian age for the Juana Lopez, and, depending on which guide fossil is present, three biozones or subzones are recognized (Dane and others, 1966). Because of its characteristic lithology and fauna and its widespread extent, the Juana Lopez is truly a remarkable unit in the Western Interior seaway.

The Juana Lopez Member is coeval to the upper half of the Ferron Sandstone Member near Ferron (fig. 9) and to at least the uppermost part of the Ferron in the Henry basin about $60 \mathrm{mi}(100 \mathrm{~km})$ southwest of Green River where Peterson and Ryder (1975) reported Prionocyclus macombi of late Turonian age. Whether or not the Juana Lopez was physically connected with the sandstones of the Ferron near Ferron cannot be demonstrated because these rocks have been eroded from the San Rafael uplift. It seems unlikely that the sandstone beds of the Ferron were connected with the 
Juana Lopez because they do not completely connect around the north plunge of the San Rafael uplift (fig. 9). Because of this and the distinctive lithology of the Juana Lopez, which is very different from the Ferron, the Juana Lopez Member probably is a separate unit from the Ferron Sandstone Member.

\section{Lower Part of Main Body of Mancos Shale}

The main body of the Mancos Shale overlies the Juana Lopez Member throughout the area. The lower $300-400 \mathrm{ft}(90-120 \mathrm{~m})$ of the main body is shown for correlation purposes on plate 1 . This part of the Mancos is very poorly exposed or covered. The lower $25 \mathrm{ft}(8 \mathrm{~m})$ exposed at control point 28 (pl. 1 , sections $A-A^{\prime}, B-B^{\prime}$ ) consists of dark-gray, noncalcareous fissile shale and is probably representative of this part of the section. Much of the overlying part of the section probably is more calcareous because it grades into the highly calcareous Niobrara Formation east of the study area. Indeed, on the northeast side of the basin and north of Rangely, the abrupt change in the color of the weathered shale rubble from medium gray to light gray about $50 \mathrm{ft}(15 \mathrm{~m})$ above the Frontier Formation is due to an increase in calcareous content (control point 13, pl. 1, section $C-C^{\prime}$ ). About $6 \mathrm{mi}(10 \mathrm{~km})$ east of this point, a 4 -in. $(10 \mathrm{~cm})$ thick bed of argillaceous limestone is present $150 \mathrm{ft}(45$ $\mathrm{m}$ ) above the Frontier. This bed contains the middle Coniacian guide fossil, Inoceramus deformis, and is probably a westward-extending tongue of the Fort Hays Limestone Member of the Niobrara Formation. The position of this bed was projected to drill hole 79 at the north end of the correlation section $C-C^{\prime}$ (pl. 1). Its approximate position was then correlated to the Farnham dome area (pl. 1, section $B-B^{\prime}$ ). Near control point 63 (fig. 2) northwest of Green River, the late Coniacian fossils, Scaphites depressus and Inoceramus stantoni, were collected from a sandy zone in the Mancos Shale 500-600 $\mathrm{ft}$ (150-180 m) above the Juana Lopez Member.

West of the Farnham dome, where the Juana Lopez is not present, the main body of the Mancos directly overlies the Ferron Sandstone Member. About $150 \mathrm{ft}(45 \mathrm{~m})$ of this part of the Mancos is fairly well exposed at control point $21 \mathrm{~A}$ (pl. 1, sections $A-A^{\prime}, B-B^{\prime}$ ). The lower half of this section consists of siltstone comprising two upward-coarsening (to lower very fine grained sandstone) sequences. This part of the section was probably deposited in a slightly restricted marine environment landward from the upper sandstone of the Ferron, which probably extended from the north as a shelf sand ridge. The upper half of the section is normal marine silty shale capped by a 7 - $\mathrm{ft}(2 \mathrm{~m})$ thick offshore shelf sandstone bed containing the upper Juana Lopez ammonite, Scaphites warreni. Thus, much of the silty shale section underlying this shelf sandstone is a lateral equivalent of the Juana Lopez Member (pl. 1, sections $\left.A-A^{\prime}, B-B^{\prime}\right)$.

\section{Correlations Around the Uinta Basin}

Molenaar and Wilson (1990) correlated middle Cretaceous rocks along the north side of the Uinta basin (fig. 14), and, because of inadequate subsurface control, they correlated across the western part of the basin between surface sections at Red Creek and the Farnham dome (figs. 2, 15). Correlations of surface sections and numerous drill-hole logs in the present study show relations across the south and east sides of the basin (pl. 1 , sections $A-A^{\prime}, B-B^{\prime}, C-C^{\prime}$ ).

The apparent thickening of the Frontier between drill hole 80 and surface section 13 at the north end of section $C-C^{\prime}$ (pl. 1) may be due, in part, to expansion of unloaded shale in steeply dipping outcrops. Thicknesses of shale sections in outcrops, especially in steeply dipping beds, commonly are greater than in adjacent wells, despite the great care taken to accurately measure the sections. Section $D-D^{\prime}$ (pl. 1) shows the correlations with wells to the northwest of drill hole 79 and completes a closed triangle with which to corroborate these significant correlations.

Relations across the south side have been discussed. Correlations along the east side (pl. 1, section $C-C^{\prime}$ ) have some regional implications. The salient features of the correlations are as follows; ramifications of some of the correlations are discussed in a following section.

The Mowry Shale grades by facies change into the Dakota Sandstone between 4 and $18 \mathrm{mi}$ ( 6 and $29 \mathrm{~km}$ ) southwest of Rangely (pl. 1, section $C-C^{\prime}$ ). In tracing this zone of facies change using drill-hole logs northwest and southeast of the line of section $C-C^{\prime}$, the depositional strike of the zone is quite irregular. This irregular strike indicates a low-energy shoreline along which fluvial processes dominated. Within this zone of intertonguing or facies change, the Dakota rises stratigraphically about $100 \mathrm{ft}(30 \mathrm{~m})$. The unconformity at the top of the Mowry Shale is correlated to the top of the Dakota Sandstone or, south of the facies change, to the base of the Mancos Shale. Correlation of drill-hole logs farther south indicates that this unconformity is the same unconformity as that at the base of the Mancos Shale (the base of the Tununk Member) on the south side of the basin, where the Mancos unconformably lies on the Cedar Mountain Formation. Beneath the unconformity, the Dakota Sandstone, which is Early Cretaceous in age on the north side of the Uinta basin, is interpreted to correlate with and grade into the upper part of the Cedar Mountain Formation on the east and south sides of the basin as 


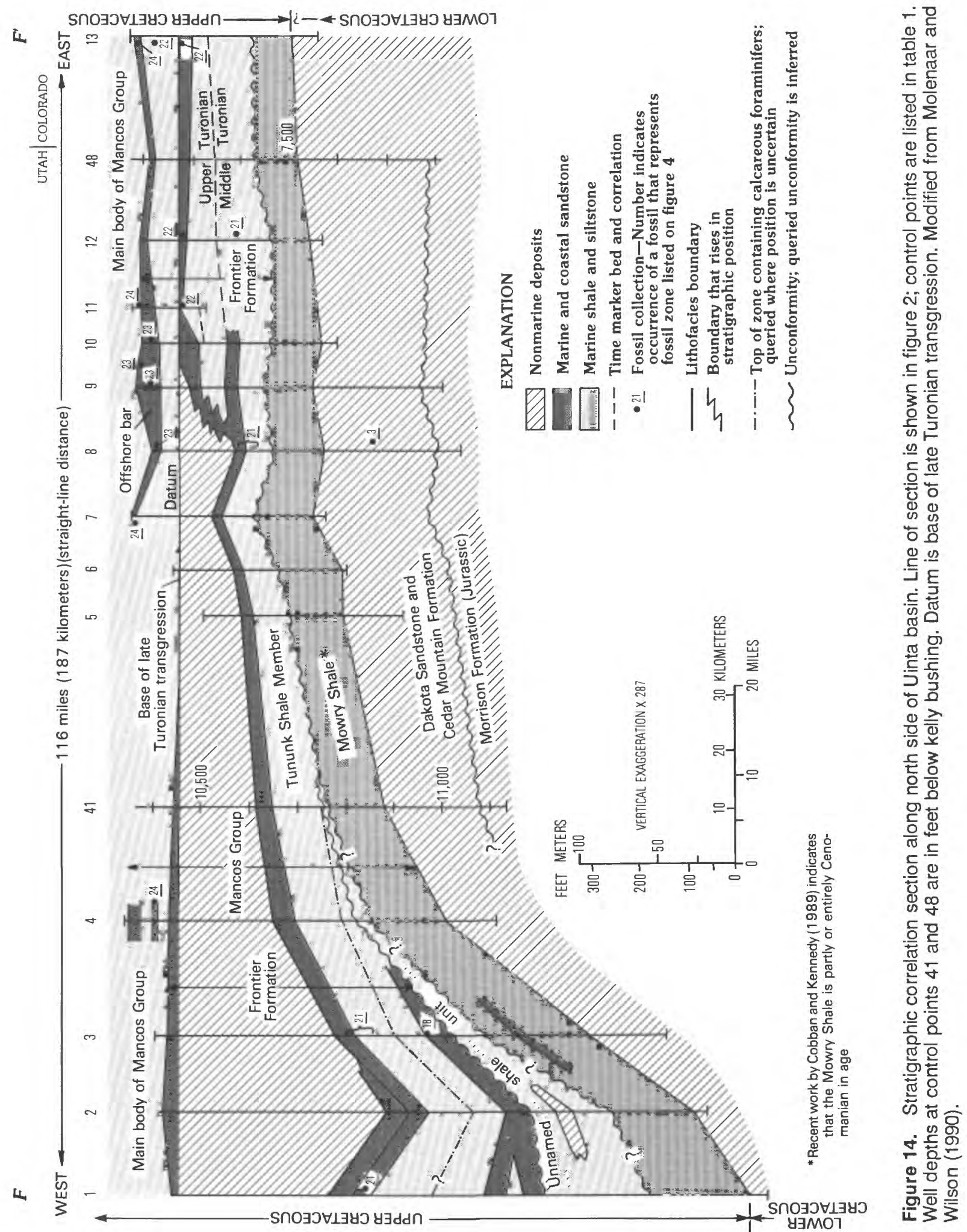


shown on section $C-C^{\prime}$ (pl. 1). In the area of, and west of, drill holes 70-72 (fig. 2, pl. 1, section $C-C^{\prime}$ ), Munger (1965) reported intertonguing of the Dakota and Cedar Mountain on the basis of detailed examination of drillhole cuttings. He differentiated the two units on the basis of dark-gray shale characterizing the Dakota and green or other pastel shale characterizing the Cedar Mountain. The Dakota in this area is here considered to be an older unit separated from rocks called Dakota on the south side of the basin by an unconformity (to be discussed). The Dakota Sandstone and Cedar Mountain Formation are shown as undifferentiated on section $C-C^{\prime}$ (pl. 1) because of difficulties in separating them on drill-hole logs.

The lower half of the Tununk Member of the Mancos Shale, including the Coon Spring Sandstone Bed, thins and onlaps the unconformity from south to north. This onlap pattern is similar to that inferred by Molenaar and Wilson (1990) for rocks of similar age in the lower part of the Frontier Formation from west to east along the north side of the Uinta basin (fig. 14).

The overlying Juana Lopez Member correlates with the upper part of the Frontier Formation; the base of the Juana Lopez correlates with rocks at the base of the abrupt stratigraphic rise of the Frontier that Molenaar and Wilson (1990) discussed. Apparently this abrupt stratigraphic rise represents an important widespread rise in relative sea level. The regressive sandstone units deposited prior to this rise are represented on the southwest side of the basin by the Ferron Sandstone Member (pl. 1, sections $A-A^{\prime}, B-B^{\prime}$ ) and on the north side of the basin by the coastal sandstone unit above the Tununk Shale Member of the Frontier west of control point 8 (fig. 14).

We place the terminology change from the upper part of the Frontier Formation to the Juana Lopez Member of the Mancos Shale on the east side of the Uinta basin at about the point where the Mowry Shale grades into the Dakota Sandstone ( $\mathrm{pl}$. 1, section $C-C^{\prime}$ ).

About $40-50 \mathrm{ft}(12-15 \mathrm{~m})$ above the Frontier Formation on the northeast side of the Uinta basin, a zone of calcareous shale is indicated by the more resistive $\log$ response (pl. 1 , sections $C-C^{\prime}, D-D^{\prime}$ ) and the lightgray-weathered shale in subdued outcrops. This zone probably is equivalent to the base of the Niobrara Formation of the Great Plains and eastern Wyoming.

\section{DISCUSSION}

The correlations and interpretations presented in this report provide additional data or ideas for speculation on (1) the extent and nature of a prominent middle Cretaceous unconformity, (2) the relation of the Dakota Sandstone on the north side of the Uinta basin to the Dakota on the south side of basin, and (3) the relation of transgressions, regressions, depositional conditions, relative sea-level changes, and eustacy.

\section{The Middle Cretaceous Unconformity}

On the northeast side of the Uinta basin, upper middle Turonian rocks of the Frontier Formation unconformably overlie lower Cenomanian rocks of the Mowry Shale (pl. 1, sections $C-C^{\prime}, D-D^{\prime}$ ). The time span represented by this unconformity is about $6 \mathrm{~m} . \mathrm{y}$. judging from the age of beds above and below the unconformity as determined by paleontologic means and radiometric ages for the biostratigraphic zonations by Obradovich and Cobban (1975) and revisions shown in figure 4. On the south side of the basin, upper Cenomanian rocks of the basal Mancos Shale (Tununk Member) unconformably overlie the upper Albian or lower Cenomanian(?) upper part of the nonmarine Cedar Mountain Formation. This time span is about 4 m.y. It is logical then that these two unconformities are the same unconformity inasmuch as a hiatus of this magnitude has not been recognized in the overlying marine rocks. Sharp (1963) did recognize or interpret a basal Turonian and a mid-Turonian unconformity in the Tununk Member (his Frontier Member) along the west flank of the Piceance basin. If these unconformities are present, their hiatuses are small compared with the hiatus between the base of the Tununk Member and the underlying Cedar Mountain Formation. Strata representing at least part of the 2 m.y. difference between the 4 and 6 m.y. hiatuses mentioned above, the lower half of the Tununk, clearly onlap the unconformity from south to north (pl. 1, section $C-C^{\prime}$ ). This relation supports the interpretation of Molenaar and Wilson (1990) that rocks of early Turonian and early middle Turonian age also onlap the unconformity from west to east on the north side of the Uinta basin (fig. 14). In addition, east of Thompson toward Grand Junction, the Dakota Sandstone that conformably underlies and intertongues with the Mancos Shale probably onlaps the unconformity from east to west. All these relations suggest that the onlapped erosion surface had topographic relief or that the feature, called the Vernal high by Molenaar and Wilson (1990), was growing during or just prior to the time of the onlapping; that is, during late Cenomanian and early middle Turonian time. Thus, the Vernal high of northeastern Utah, northwestern Colorado, and part of adjacent Wyoming was an offshore shoal or island in early and early middle Turonian time. The upper part of the Mowry Shale and possibly other lower Cenomanian rocks probably were eroded from the high, but the onlap relations just described indicate that upper Cenomanian through lower middle Turonian rocks were never deposited on the crest of the high. 
Red Creek

Farnham dome

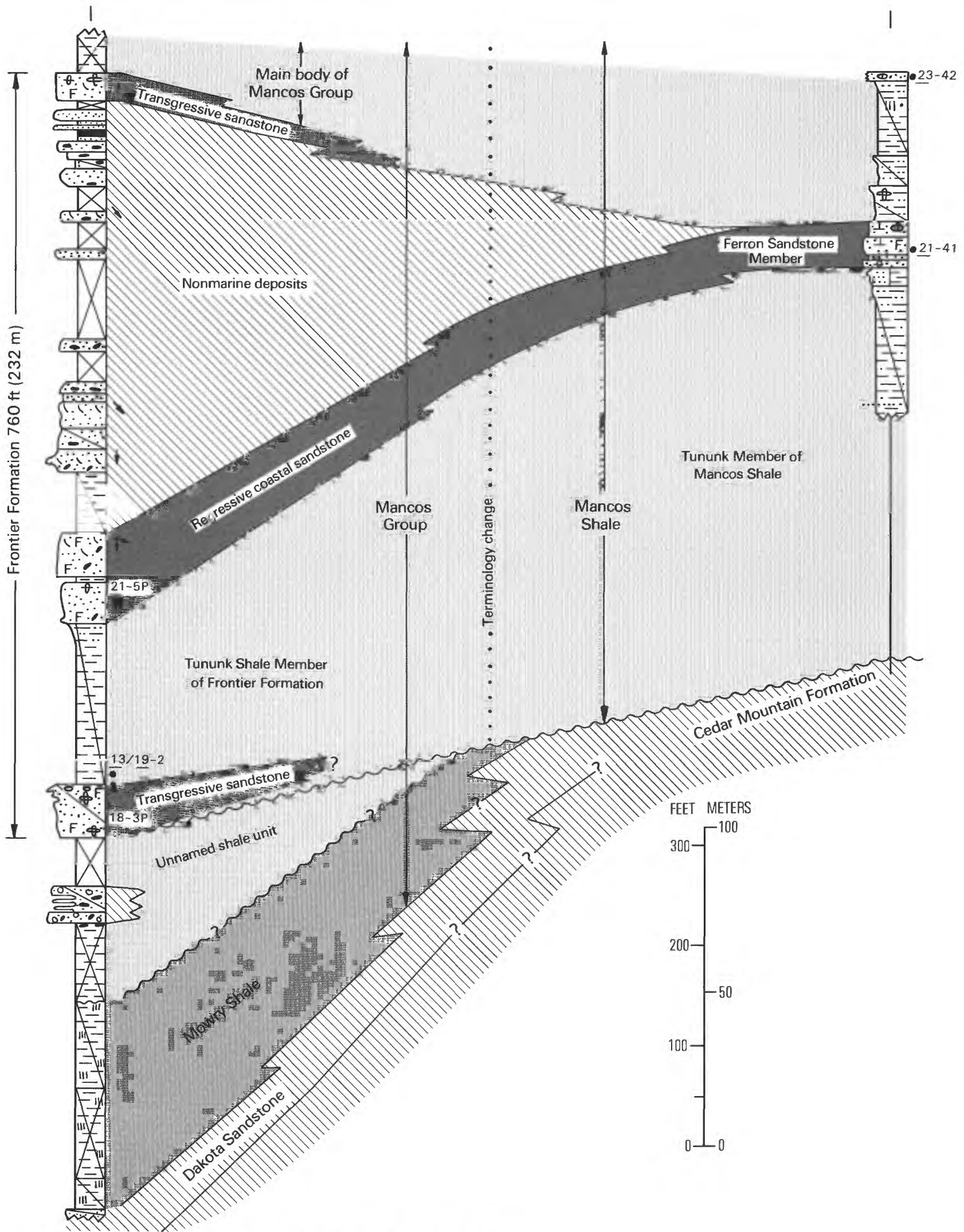




\section{EXPLANATION}

ACCESSORIES, MODIFIERS, AND SEDIMENTARY STRUCTURES

- Pebbles

Shale clasts or galls

(1) Concretions

- Carbonaceous

$\perp$ Calcareous

III Bentonite or bentonitic

Crossbedded

$\theta$ Trace fossils (burrows)

$\circledast$ Bioturbated (churned)

डा Root casts

F Fossiliferous

\section{LITHOFACIES PATTERNS}

Nonmarine deposits

Marine and coastal sandstones

Marine shale and siltstone

\section{MISCELLANEOUS}

21-41 - Zone fossil (underlined) and collection number (see fig. 4 and table 2 )

Current direction from crossbeds

\section{BOUNDARIES AND CORRELATIONS}
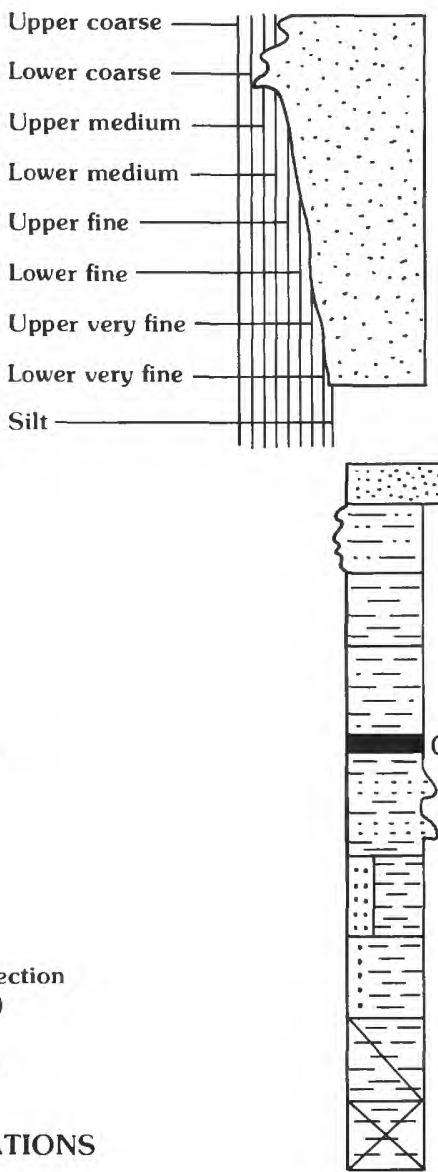

Sandstone. On sections where column excursion is to left, column width indicates visual estimate of average grain size. Single row of dots extending outside of column represents a thin $(<1 \mathrm{ft})$ layer of coarser grains, the size of which is indicated. In essence, the left side of the column is a grain-size profile
Sandstone. On section where column excursion is to right, no specific grain size is implied

Siltstone

Shale or claystone

Silty shale or mudstone

C Coal

Interbedded sandstone and shale or siltstone; generalized thick interval

Interbedded sandstone and shale or siltstone in which sandstone beds are too thin or too subdued to separate from sequence. Proportions of each are indicated

Interbedded sandstone and shale or siltstone in which sandstone proportions is less than 20 percent

Partially covered interval

Covered interval; lithology inferred if filled in

Lithofacies boundary

$\checkmark$ Boundary that rises in stratigraphic position

$\sim$ Unconformity: queried where position is uncertain

- - - Top of zone containing calcareous foraminifers

Figure 15 (above and facing page). Stratigraphic correlation section of middle Cretaceous rocks between Red Creek on the north side of the Uinta basin and the Farnham dome on the south side. Line of section is shown in figure 2; control points are listed in table 1. Vertical exaggeration $\times 422$. Fossil collections designated by $P$ at Red Creek are projected from sections to the east. From Molenaar and Wilson (1990).

Figure 16 shows the distribution and lithofacies of lower middle Turonian rocks (upper part of Collignoniceras woollgari zone), the Coon Spring Sandstone Bed and equivalent rocks. The Coon Spring apparently was deposited as an apron on the south side of the Vernal high, and sediments of the Coon Spring may have been derived from the high. The broad axis of the high, if such could be defined on this feature, probably trended generally north-south as shown by Merewether and Cobban (1986). The slope of the unconformity between control points 71 and 75 (pl. 1, section $C-C^{\prime}$, fig. 6), as measured and calculated on a converging marker bed, is about $2.4 \mathrm{ft} / \mathrm{mi}(0.45 \mathrm{~m} / \mathrm{km})$. Allowing for compaction, the original slope would have been slightly steeper.

South of the Uinta basin, this significant unconformity or disconformity (4 m.y. time span) continues at the base of the Mancos Shale or Dakota Sandstone throughout southern Utah, southwestern Colorado, and as far south as the Dakota and Mancos extend. In Arizona and New Mexico, progressively older Mesozoic and Paleozoic rocks underlie the Dakota or equivalent rocks to the south and southwest (Dane and 


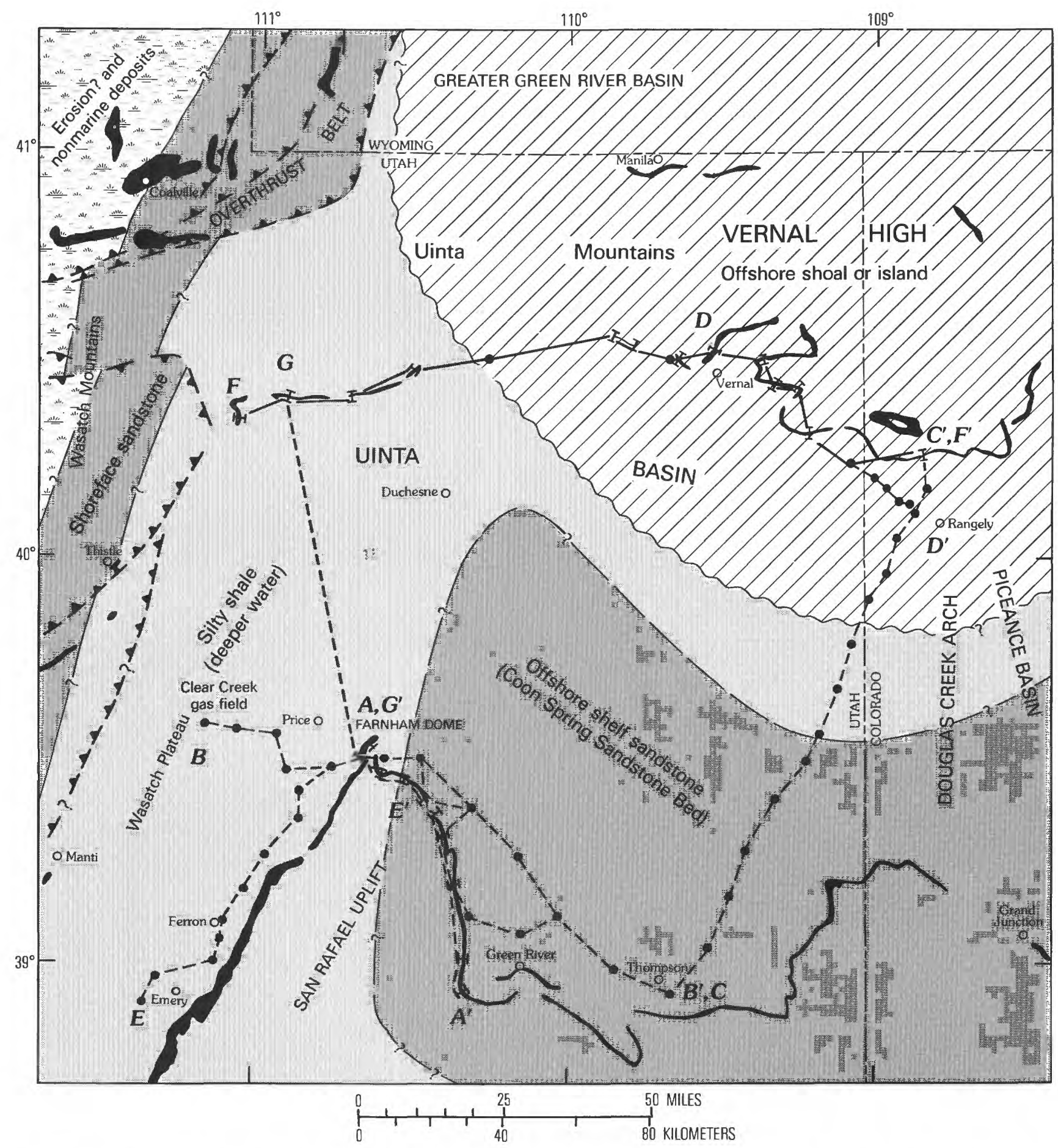

Figure 16. Distribution and lithofacies of the Coon Spring Sandstone Bed of the Tununk Member of the Mancos Shale and equivalent rocks (upper part of Collignoniceras woollgari zone, lower middle Turonian).

Bachman, 1965; Wilson and others, 1969; Reynolds, 1988). West of Silver City in southwestern New Mexico, the Cenomanian Beartooth Quartzite, a correlative of the Dakota Sandstone, overlies Precambrian crystalline rocks.

\section{Two Dakota Sandstone Units}

The Dakota Sandstone on the north side of the Uinta basin underlies the Mowry Shale and is probably Albian in age. The Dakota on the southeast side of the 
basin is middle or late Cenomanian in age. Formerly, the Dakota on the north side of the basin was thought to connect with the younger Dakota on the south side of the basin by a normal time-transgressive relation (McGookey and others, 1972); however, the correlation of the unconformity above the Mowry on the north side with the unconformity at the base of the Tununk Member of the Mancos on the south side (pl. 1, section $C-C^{\prime}$ ) indicates that the two Dakotas are not timetransgressive equivalents, at least along the line of section. Similar to the lower part of the Tununk, which clearly onlaps the unconformity from south to north, the Dakota on the southeast side of the basin, which we consider as part of the Tununk depositional cycle, probably also onlaps the unconformity. Thus, the Dakota on the south side of the basin is separated from the Dakota on the north side by a regional unconformity (fig. 3 ). The unconformity probably dies out, and the two units are connected by means of a time-transgressive relation east of the Piceance basin.

\section{Transgressions, Regressions, Depositional Conditions, Relative Sea-Level Changes, and Eustacy}

The marine middle Cretaceous rocks discussed in this report were deposited during one major transgressive-regressive cycle and the lower part of the next transgressive-regressive cycle. These cycles, known as the Greenhorn and Niobrara cyclothems (Hattin, 1962; Kauffman, 1969), are recognized along much of the Western Interior seaway and have been related to global sea-level changes (Hancock and Kauffman, 1979), although basinal tectonics are also involved. The separation of the effects of these two factors is a difficult problem that needs to be addressed but is beyond the scope of this report.

In addition to separating tectonic effects acting within the basin from eustatic sea-level changes, a problem in correlating relative sea-level changes observed in the Western Interior with charts of global eustatic sea-level changes is the accuracy in dating events. Dating of Western Interior events is based mostly on Western Interior molluscan fossil zones tied to a few (never enough) radiometrically dated ash beds (Obradovich and Cobban, 1975). Global eustasy charts for the middle Cretaceous are based on ages of continentalmargin micro- and macro-fossils, tied to radiometrically dated rocks (Haq and others, 1988), and, as new data become available, the charts must be revised. In the following discussion, we attempt to relate depositional sequences and lithologic types observed in the study area to depositional conditions, relative sea-level changes, and the effects of eustacy. Figure 17 shows global sea-level curves for part of middle Cretaceous time.

The lowermost part of the Tununk Member of the Mancos Shale was deposited during the late Cenomanian-early Turonian Greenhorn transgression. This probably was a worldwide eustatic event (Hancock and Kauffman, 1979) that, using the eustatic sea-level curve of Haq and others (1988), correlates with a sealevel high stand that culminated about $91.5 \mathrm{Ma}$ (fig. 17). This part of the Tununk consists of clay shale that becomes silty upward as the result of regression and shallowing. A broad shallowing or shoaling of the sea as represented by the Coon Spring Sandstone Bed may be the result of a minor eustatic fall in sea level about 91 $\mathrm{Ma}$, although tectonism related to the Vernal high (fig. 16) probably was an important cause of the shoaling. Even though the Coon Spring Sandstone Bed does not

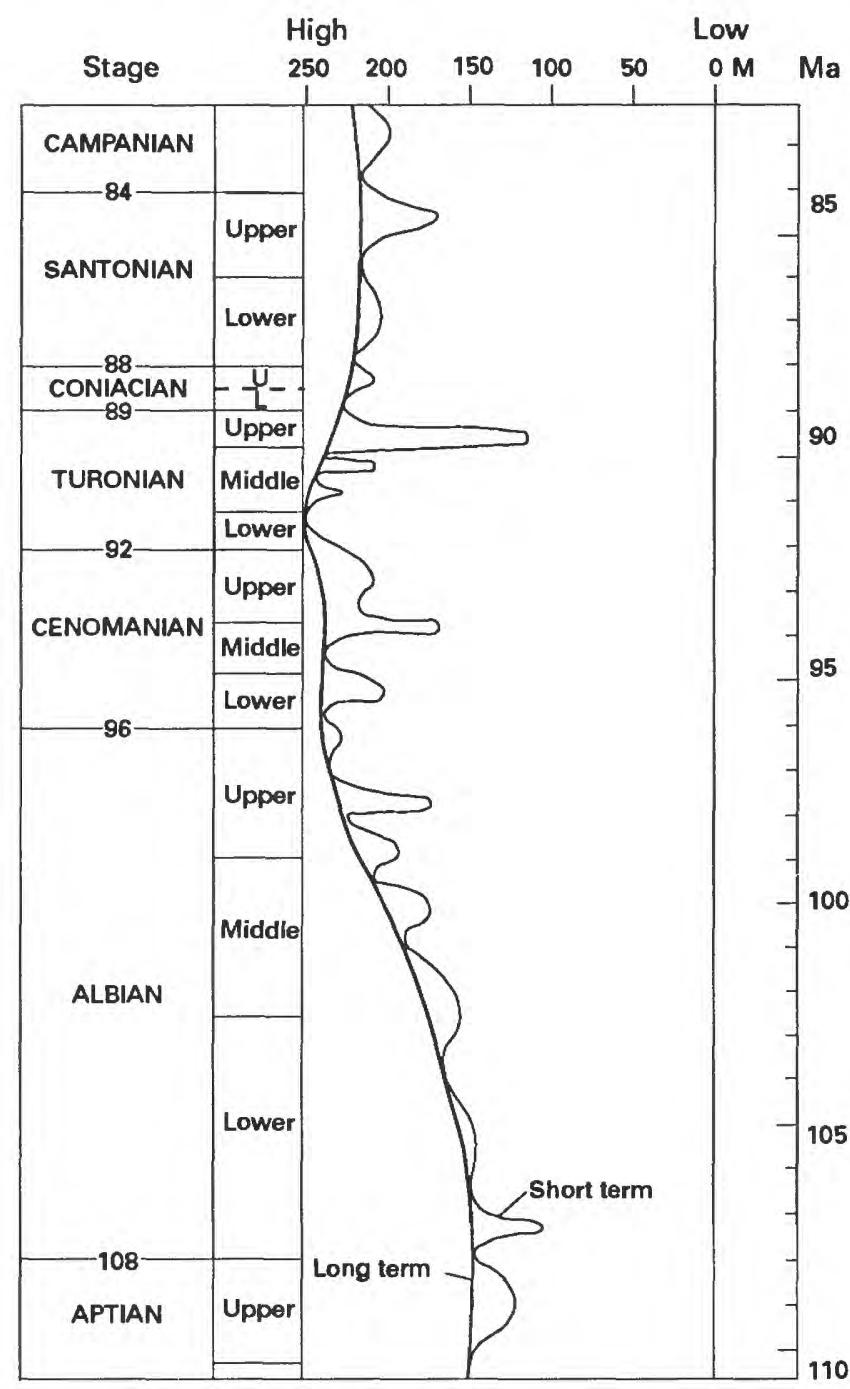

Figure 17. Long- and short-term eustatic sea-level curves for most of middle Cretaceous time. Modified from Haq and others (1988). 
seem to be developed where equivalent siltstones intersect the unconformity, at least some of the sand for the Coon Spring may be from reworking of the underlying Dakota Sandstone on the Vernal high during a stillstand in Coon Spring time. The sandstones of the Dakota are well developed at this intersection, which is just landward from the Dakota-Mowry transition (pl. 1, section $C-C^{\prime}$ ). The grading of the Coon Spring Bed to siltstone on the west is probably due to subsidence rates exceeding depositional rates, resulting in deeper water in that area (fig. 5). Figure 16 shows the inferred distribution of the Coon Spring Sandstone Bed and the onlap edge of Coon Spring-equivalent siltstone.

Following slight slow subsidence after deposition of the Coon Spring Bed, silty shale of the upper part of the Tununk was deposited in an offshore environment in which the shale grades upward into siltstone and, on the northwest, into offshore shelf or lower shoreface sandstone of the Ferron Sandstone Member. Except for possibly the lowermost part of the Tununk, normally oxygenated marine conditions prevailed during Tununk time, as indicated by abundant burrowing and bioturbation in both the Tununk and Ferron Members.

\section{Ferron Sandstone Member}

The regressive cycle that culminated with deposition of the Ferron Sandstone Member has been attributed to a eustatic fall of sea level (Ryer and McPhillips, 1983; Ryer and Lovekin, 1986). As these authors suggested, however, the effects of the sea-level drop were offset in some areas by tectonic subsidence. We believe that tectonic subsidence masks the sea-level drop throughout much of the study area. Certainly in the area west of the Farnham dome, the rapid thickening of the middle Cretaceous section is due to tectonic effects; that is, increased subsidence rates (pl. 1, section $B-B^{\prime}$, fig. 5).

We suggest that if the middle Turonian Ferron regression in the study area correlates with a global eustatic fall in sea level, it would correlate with the eustatic fall about $89.7 \mathrm{Ma}$ (fig. 17). It should be noted again that the Ferron of the study area is equivalent to only the lower part of the Ferron of the Ferron area-the lower Ferron of Ryer and McPhillips (1983) (fig. 9). The upper part of the Ferron at Ferron, which is late Turonian in age, was deposited during a relative (and eustatic) sea-level rise-a case of clastic input from a northeasterly prograding delta dominating the depositional pattern.

Figure 18 shows the inferred shoreline and extent of shoreface and shelf sandstones of the Ferron Member and Frontier Formation at the end of middle Turonian time (zone of Prionocyclus hyatti).

\section{Juana Lopez Member}

The Ferron Sandstone Member and the seawardequivalent siltstone of the Tununk Member are, in most places, abruptly overlain by fissile clay shale of the Juana Lopez Member. The boundary is a marine flooding surface that marks the middle and upper Turonian boundary and an important transgression or deepening of the seaway in many parts of the Western Interior. It is the beginning of the Niobrara cyclothem. On the north side of the Uinta basin, the abrupt stratigraphic rise of the prograding coastal sandstone of the Frontier Formation reported by Molenaar and Wilson (1990) occured precisely at this time according to our correlations (pl. 1, section $C-C^{\prime}$, fig. 14). In the terminology of Van Wagoner and others (1988), the stratigraphically rising coastal sandstone is an aggradational parasequence set of a transgressive systems tract. As already mentioned, the stacking of several coastal sandstones of the upper part of the Ferron at the south end of Castle Valley also indicates a relative sea-level rise (Ryer, 1981; Ryer and McPhillips, 1983). In west-central New Mexico, south of the San Juan basin, the D-Cross or Pescado transgression occurred at this time (Hook and others, 1983; Molenaar, 1983), and, in fact, the Juana Lopez Member has been traced into these transgressive shale units. If this relative sea-level rise was related to eustasy rather than basin subsidence, we would correlate it to a global rise about $89.5-89 \mathrm{Ma}$ (fig. 17). Figure 19 shows the inferred position of the shoreline and shoreface and shelf sandstones of the Ferron Member and Frontier Formation during middle Juana Lopez time (zone of Prionocyclus macombi).

\section{Lower Part of Main Body of Mancos Shale}

The lower part of the main body of the Mancos Shale, a continuation of the Niobrara cyclothem, was deposited after another transgressive event in which the shoreline to the west and northwest of the study area was much farther landward than the Juana Lopez shoreline (figs. 5, 9, 14). This transgression reached its peak in early or middle Coniacian time west and northwest of the Uinta basin. Inoceramus deformis (middle Coniacian) is present in the upper part of a marine shale tongue in the middle of the Funk Valley Formation on the west side of the Wasatch Plateau. The base of this shale tongue is probably early Coniacian in age and probably correlates with the calcareous shale that is considered equivalent to the base of the Niobrara Formation on the northeast side of the Uinta basin ( $\mathrm{pl} .1$, sections $C-C^{\prime}, D-D^{\prime}$ ). Inoceramus deformis also is present in sandstones above and below the Judd Shale Member of the Frontier Formation in the Coalville area (fig. 2). This transgressive peak may correlate with the short-term high stand of Haq and others (1988) about 88.7 Ma (fig. 17). 


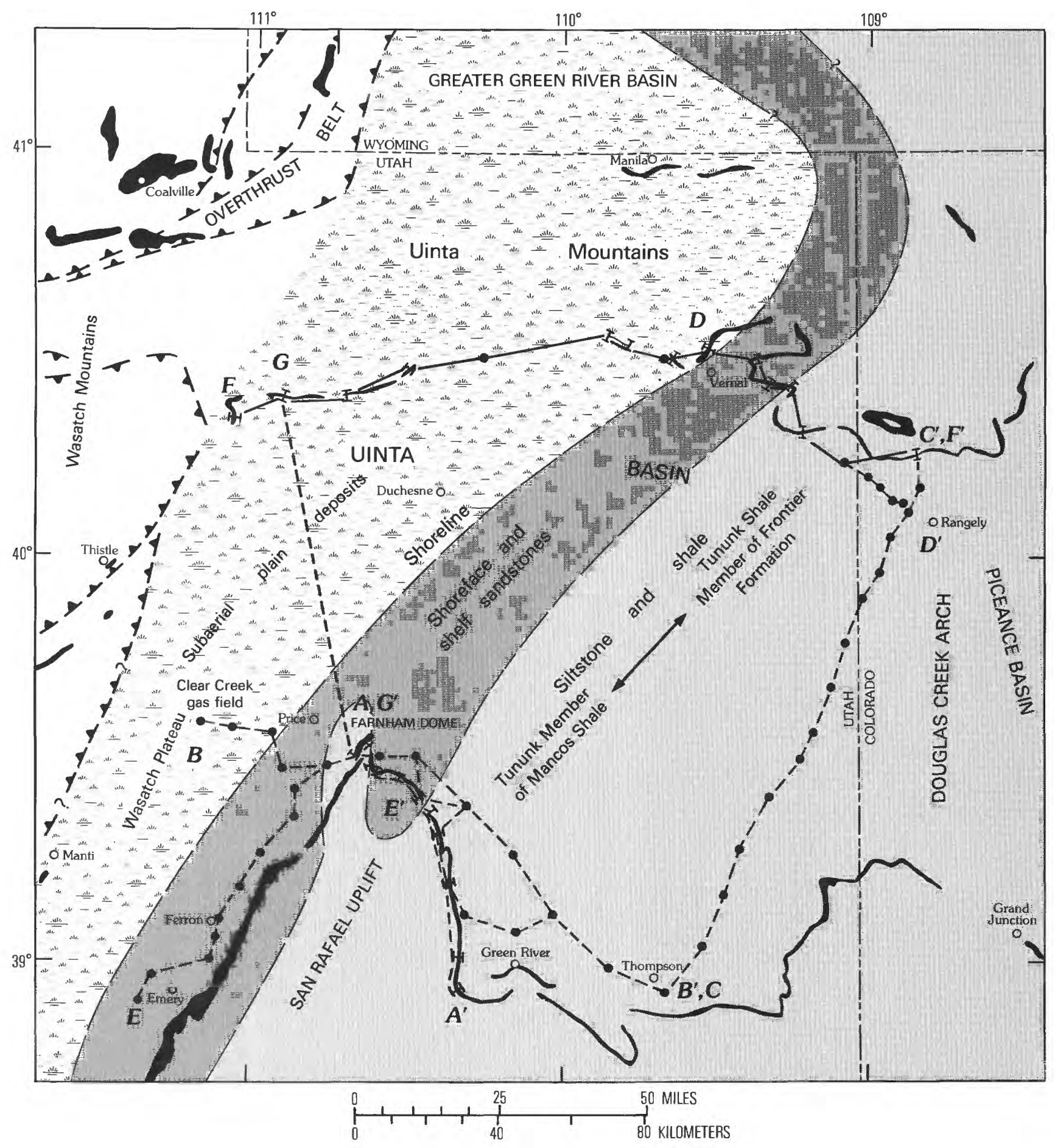

Figure 18. Distribution and lithofacies of rocks deposited at the end of middle Turonian time (Prionocyclus hyatti zone). Subaerial plain deposits and shoreface shelf sandstones are parts of the Ferron Sandstone Member of the Mancos Shale (south) and Frontier Formation (north). Siltstone and shale are part of the Tununk Member of the Mancos Shale. 


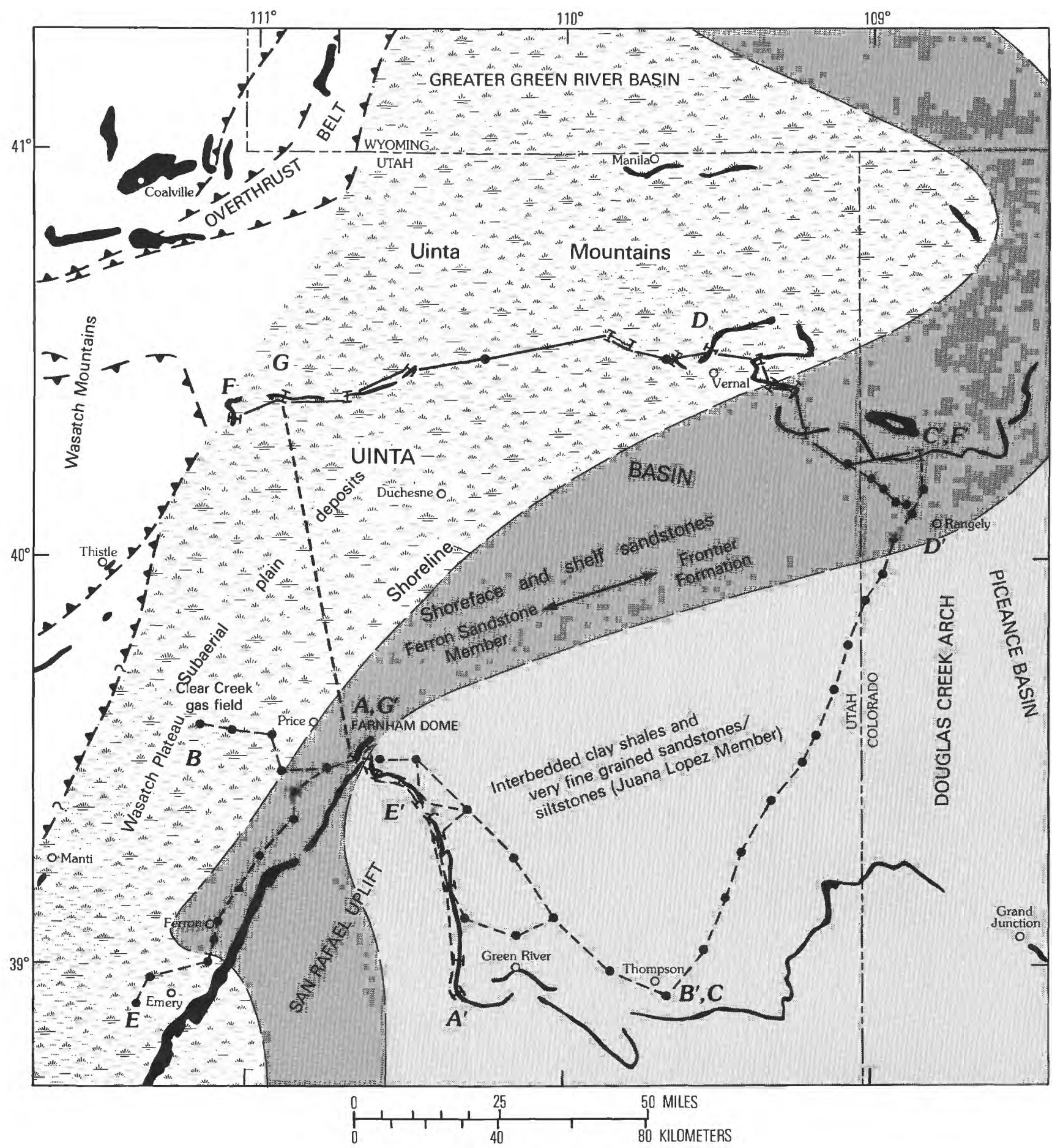

Figure 19. Distribution and lithofacies of rocks deposited at time of maximum regression of Vernal delta during late Turonian time (middle of Prionocyclus macombizone). Subaerial plain deposits and shoreface and shelf sandstones are parts of the Ferron Sandstone Member of the Mancos Shale (south) and the Frontier Formation (north). Interbedded rocks are part of Juana Lopez Member of the Mancos Shale. 
A 30-40-ft (9-12 m) thick sandstone unit containing late Coniacian fossils is present in the Mancos Shale about 500-600 ft $(150-180 \mathrm{~m})$ above the Juana Lopez Member north of Green River and could conceivably represent deposition during a short-term low stand at 88.3 Ma.

\section{SUMMARY AND CONCLUSIONS}

The integration of surface and subsurface (drill hole) data has greatly enhanced the resolution of stratigraphic correlations and attendant stratigraphic problems. Analysis of carefully measured surface sections resulted in better definition of rock types, bedding features, direction features, contact relations, and depositional environments. In addition, zone fossils that were collected provided critical biostratigraphic data to support the correlations. Recognition of contrasts in lithology or marker beds that are apparent on both surface sections and drill-hole logs, such as the sharp contact of a clay shale overlying a sandstone bed or a thick bentonite bed, facilitated the correlation of a surface section with a nearby drill hole. Thus, longdistance correlations of numerous marker beds in the marine shale that were recognized on logs, primarily the conductivity $\log$, provided a time framework in which to recognize facies changes of rock units, depositional thinning or onlap of strata, and other depositional features. This approach was crucial to the interpretations and documentation of data presented in this report.

Stratigraphic analysis, based mostly on outcrop studies on the south side of the Uinta basin, indicates that (1) the Mancos Shale unconformably overlies the Cedar Mountain Formation over most of the area, (2) the middle Turonian Ferron Sandstone Member of the Man$\cos$ Shale grades southeastward into siltstone of the Tununk Member of the Mancos Shale between Price and Green River, and (3) the cuesta-forming upper Turonian Juana Lopez Member of the Mancos Shale, which was previously mapped as Ferron Sandstone Member in the study area, overlies the Ferron Member, where it is present southeast of the Farnham dome, and the Tununk Member farther to the east and southeast.

Subsurface correlations across the east and northeast sides of the Uinta basin and tied to surface control at each end of the correlation section show that (1) the Mowry Shale grades southward into the Dakota Sandstone, which in turn grades southward into the upper part of the Cedar Mountain Formation; (2) the about 6 m.y. unconformity that separates the Mowry Shale from the overlying shale of the Frontier Formation on the northeast side of the Uinta basin is the same as the about 4 m.y. unconformity that separates the Mancos Shale from the Cedar Mountain Formation on the south side; (3) strata representing at least part of the about 2 m.y. difference, including the Coon Spring Sandstone Bed (new name) of the Tununk Member, onlap the unconformity from south to north along the east side of the basin; (4) the Dakota Sandstone, where present on the southeast side, is younger than the Dakota on the north side and is separated from it by an unconformity; and (5) the base of the Juana Lopez Member (a marine flooding surface) correlates with the base of an abrupt stratigraphic rise of the shoreface sandstone in the Frontier Formation on the northeast side of the basin, thus confirming that this rise or flooding surface represented a widespread relative sea-level rise. The Juana Lopez, which consists of interbedded fissile clay shale and very fine grained sandstone or siltstone (storm deposits), is a distal equivalent of the upper part of the Frontier Formation of northeastern Utah and the upper part of the Ferron Sandstone Member of the FerronEmery area of Castle Valley, Utah.

The suggested correlations of the transgressive and regressive events recognized in this report with global eustatic sea-level curves may be premature. Certainly some of these events or cycles, which can be recognized over wide areas within the Western Interior basin, may be related to basin tectonism. To confidently relate these events to eustatic sea-level changes, more or better radiometric ages as well as biostratigraphic control are required between continents.

\section{REFERENCES CITED}

Bozanic, Dan, 1955, A brief discussion on the subsurface Cretaceous rocks of the San Juan Basin, in Cooper, J.C., ed., Geology of part of Paradox, Black Mesa and San Juan Basins: Four Corners Geological Society Field Conference, 1st, Guidebook, p. 89-107.

Cobban, W.A., 1976, Ammonite record from Mancos Shale of the Castle Valley-Price-Woodside area, east-central Utah: Brigham Young University, Geology Studies, v. 22, pt. 3, p. 117-126.

Cobban, W.A., and Kennedy, W.J., 1989, The ammonite Metengonoceras Hyatt, 1903, from the Mowry Shale (Cretaceous) of Montana and Wyoming: U.S. Geological Survey Bulletin 1787-L, 11 p.

Cotter, E., 1975, Late Cretaceous sedimentation in a lowenergy coastal zone-The Ferron Sandstone of Utah: Journal of Sedimentary Petrology, v. 45, p. 669-685.

Craig, L.C., 1981, Lower Cretaceous rocks, southwestern Colorado and southeastern Utah, in Wiegand, D.L., ed., Geology of the Paradox basin: Rocky Mountain Association Geologists Field Conference, 1981, Guidebook, p. 195-200.

Craig, L.C., Holmes, C.N., Cadigan, R.A., Freeman, V.L., Mullens, T.E., and Weir, G.W., 1955, Stratigraphy of the Morrison and related formations, Colorado Plateau region, a preliminary report: U.S. Geological Survey Bulletin 1009-E, p. 125-168. 
Craig, L.C., and others, 1961, Discussion of "Dakota Group of Colorado Plateau," by R.G. Young (1960): American Association of Petroleum Geologists Bulletin, v. 45, no. 9, p. 1582-1591.

Dane, C.H., 1935, Geology of the Salt Valley anticline and adjacent areas, Grand County, Utah: U.S. Geological Survey Bulletin 863, $184 \mathrm{p}$

Dane, C.H., and Bachman, G.O., 1965, Geologic map of New Mexico: U.S. Geological Survey, scale 1:500,000.

Dane, C.H., Cobban, W.A., and Kauffman, E.G., 1966, Stratigraphy and regional relationships of a reference section for the Juana Lopez Member, Mancos Shale, in the San Juan Basin, New Mexico: U.S. Geological Survey Bulletin 1224-H, 15 p.

Doelling, H.H., 1985, Geologic map of Arches National Park and vicinity, Grand County, Utah, Map 74: Utah Geological and Mineralogical Survey, scale 1:50,000.

Eaton, J.G., Kirkland, J.I., and Kauffman, E.G., 1990, Evidence and dating of mid-Cretaceous tectonic activity in the San Rafael swell, Emery County, Utah: The Mountain Geologist, v. 27, no. 2, p. 39-45.

Eicher, D.L., 1965, Foraminifera and biostratigraphy of the Graneros Shale: Journal of Paleontology, v. 39, no. 5, p. 875-909.

Fisher, D.J., Erdmann, C.E., and Reeside, J.B., Jr., 1960, Cretaceous and Tertiary formations of the Book Cliffs, Carbon, Emery, and Grand Counties, Utah, and Garfield and Mesa Counties, Colorado: U.S. Geological Survey Professional Paper 332, 80 p.

Fouch, T.D., Lawton, T.F., Nichols, D.J., Cashion, W.B., and Cobban, W.A., 1983, Patterns and timing of synorogenic sedimentation in Upper Cretaceous rocks of central and northeastern Utah, in Reynolds, M.W., and Dolly, E.D., eds., Mesozoic paleogeography of the west-central United States: Rocky Mountain Section, Society of Economic Paleontologists and Mineralogists, Rocky Mountain Paleogeography Symposium 2, p. 201-224.

Gaultieri, J.L., 1988, Geologic map of the Westwater $30^{\prime} \times 60^{\prime}$ quadrangle, Grand and Uintah Counties, Utah and Garfield and Mesa Counties, Colorado: U.S. Geological Survey Miscellaneous Investigations Series Map I-1765, scale 1:100,000.

Gilbert, G.K., 1877, Report on the geology of the Henry Mountains [Utah]: U.S. Geographical and Geological Survey Rocky Mountain Region (Powell), 160 p.

Hale, L.A., 1972, Depositional history of the Ferron Formation, central Utah, in Plateau-Basin and Range transition zone, central Utah: Utah Geological Association, p. 29-40.

Hancock, J.M., and Kauffman, E.G., 1979, The great transgressions of the Late Cretaceous: Journal of the Geological Society of London, v. 136, p. 175-186.

Haq, B.U., Hardenbol, J., and Vail, P.R., 1988, Mesozoic and Cenozoic chronostratigraphy and cycles of sea-level changes, in Wilgus, C.K., and others, eds., Sea-level changes-An integrated approach: Society of Economic
Palentologists and Mineralogists Special Publication 42, p. 71-108.

Hattin, D.E., 1962, Stratigraphy of the Carlile Shale (Upper Cretaceous) in Kansas: Kansas Geological Survey Bulletin 156, 155 p.

Hintze, L.F., and Stokes, W.L., 1964, Geologic map of southeastern Utah: University of Utah College of Mines and Mineral Industries, scale 1,250,000.

Hook, S.C., and Cobban, W.A., 1980, Reinterpretation of type section of Juana Lopez Member of Mancos Shale: New Mexico Geology, v. 2, no. 2, p. 17-22.

Hook, S.C., Molenaar, C.M., and Cobban, W.A., 1983, Stratigraphy and revision of nomenclature of upper Cenomanian to Turonian (Upper Cretaceous) rocks of west-central New Mexico, in Hook, S.C., compiler, Contributions to mid-Cretaceous paleontology and stratigraphy of New Mexico-Part II: New Mexico Bureau of Mines and Mineral Resources Circular 185, p. 7-28.

Hunt, C.B., and Miller, R.L., 1946, General geology of the region-Stratigraphy, in Hunt, C.B., 1946, Guidebook to the geology and geography of the Henry Mountain region: Utah Geological Society Guidebook, no. 1, p. 6-10.

Katich, P.J., 1956, Some notes on the Cretaceous faunas of eastern Utah and western Colorado, in Peterson, J.A., ed., Geology and economic deposits of east-central Utah: Intermountain Association of Petroleum Geologists Annual Field Conference, 7th, Guidebook, p. 116-119.

Kauffman, E.G., 1969, Cretaceous marine cycles of the Western Interior: The Mountain Geologist, v. 6, no. 4, p. 227-245.

1977, Geological and biological overview-Western Interior Cretaceous basin: The Mountain Geologist, v. 14, nos. 3 and 4, p. 75-99.

Kauffman, E.G., Powell, J.D., and Hattin, D.E., 1969 , Cenomanian-Turonian facies across the Raton basin: The Mountain Geologist, v. 6, no. 3, p. 93-118.

Kowallis, B.J., and Heaton, J.S., 1987, Fission-track dating of bentonites and bentonitic mudstone from the Morrison Formation in central Utah: Geology, v. 15, no. 12, p. 1138-1142.

Lessard, R.H., 1973, Micropaleontology and paleoecology of the Tununk Member of the Mancos Shale: Utah Geological and Mineralogical Survey Special Studies 45, $28 \mathrm{p}$.

Lupton, C.T., 1916, Geology and coal resources of Castle Valley in Carbon, Emery, and Sevier Counties, Utah: U.S. Geological Survey Bulletin 628, 88 p.

McGookey, D.P., and others, 1972, Cretaceous System, in Geologic atlas of the Rocky Mountains: Rocky Mountain Association of Geologists, p. 190-228.

Merewether, E.A., and Cobban, W.A., 1986, Biostratigraphic units and tectonism in the mid-Cretaceous foreland of Wyoming, Colorado, and adjoining areas, in Peterson, J.A., ed., Paleotectonics and sedimentation in the Rocky Mountain region, United States, part III, middle Rocky Mountains: American Association of Petroleum Geologists Memoir 41, p. 443-467. 
Mitchell, J.G., 1956, Charophytes as a guide to distinguishing between Lower Cretaceous and Upper Jurassic continental sediments in the subsurface, in Peterson, J.A., ed., Geology and economic deposits of east-central Utah: Intermountain Association of Petroleum Geologists Annual Field Conference, 7th, Guidebook, p. 105-112.

Molenaar, C.M., 1975, Some notes on Upper Cretaceous stratigraphy of the Paradox basin, in Fassett, J.E., ed., Canyonlands country: Four Corners Geological Society Field Conference, 8th, Guidebook, p. 191-192.

1983, Major depositional cycles and regional correlations of Upper Cretaceous rocks, southern Colorado Plateau and adjacent areas, in Reynolds, M.W., and Dolly, E.D., eds., Mesozoic paleogeography of the west-central United States: Rocky Mountain Section, Society of Economic Paleontologists and Mineralogists, Rocky Mountain Paleogeography Symposium 2, p. 201-224.

Molenaar, C.M., and Wilson, B.W., 1990, The Frontier Formation and associated rocks of northeastern Utah and northwestern Colorado: U.S. Geological Survey Bulletin 1787-M, 21 p.

Munger, R.D., 1965, Subsurface exploration mapping, southern Uinta basin, Castlegate and Dakota-Cedar Mountain Formations: The Mountain Geologist, v. 2, no. 3, p. 141-166.

Obradovich, J.D., and Cobban, W.A., 1975, A time-scale for the Late Cretaceous of the Western Interior of North American, in Caldwell, W.G.E., ed., The Cretaceous System in the Western Interior of North America: Geological Association of Canada Special Paper 13, p. $31-54$.

Palmer, A.R., 1983, The Decade of North American Geology 1983 geologic time scale: Geology, v. 11, p. 503-504.

Peterson, Fred, 1988, A synthesis of the Jurassic System in the southern Rocky Mountain region, in Sloss, L.L., ed., Sedimentary cover-North American craton; U.S.: Geological Society of America, The Geology of North America, v. D-2, p. 65-76.

Peterson, Fred, and Ryder, R.T., 1975, Cretaceous rocks in the Henry Mountains region, Utah and their relation to neighboring regions, in Fassett, J.E., ed., Canyonlands country: Four Corners Geological Society Field Conference, 8th, Guidebook, p. 167-189.

Quigley, M.D., 1959, Correlation of the Dakota-Cedar Mountain-Morrison sequence along the Douglas arch, in Haun, J.D., and Weimer, R.J., eds., Symposium on Cretaceous rocks of Colorado and adjacent areas: Rocky Mountain Association of Geologists Field Conference, 11th, Guidebook, p. 33-36.

Rankin, C.H., 1944, Stratigraphy of the Colorado group, Upper Cretaceous, in northern New Mexico: New Mexico School of Mines Bulletin 20, 27 p.

Reeside, J.B., Jr., and Cobban, W.A., 1960, Studies of the Mowry Shale (Cretaceous) and contemporary formations in the United States and Canada: U.S. Geological Survey Professional Paper 355, 126 p.
Reynolds, S.J., 1988, Geologic map of Arizona, map 26: U.S. Geological Survey and Arizona Geological Society, scale $1: 1,000,000$.

Richardson, G.B., 1909, Reconnaissance of the Book Cliffs coal field, between Grand River, Colorado, and Sunnyside, Utah: U.S. Geological Survey Bulletin 371, 54 p.

Ryer, T.A., 1981, Deltaic coals of Ferron Sandstone Member of Mancos Shale-Predictive model for Cretaceous coalbearing strata of Western Interior: American Association of Petroleum Geologists Bulletin, v. 65, p. 2323-2340.

Ryer, T.A., and Lovekin, J.R., 1986, The Upper Cretaceous Vernal delta of Utah; depositional or paleotectonic feature?, in Peterson, J.A., ed., Paleotectonics and sedimentation in the Rocky Mountain region, United States, part III, middle Rocky Mountains: American Association of Petroleum Geologists Memoir 41, p. 497-510.

Ryer, T.A., and McPhillips, Maureen, 1983, Early Late Cretaceous paleogeography of east-central Utah, in Reynolds, M.W., and Dolly, E.D., eds., Mesozoic paleogeography of the west-central United States: Rocky Mountain Section, Society of Economic Paleontologists and Mineralogists, Rocky Mountain Paleogeography Symposium 2, p. 253-272.

Scott, G.R., 1964, Geology of the Northwest and Northeast Pueblo quadrangles, Colorado: U.S. Geological Survey Miscellaneous Investigations Series Map I-408, scale $1: 24,000$.

Sharp, J.V.A., 1963, Unconformities within basal marine Cretaceous rocks of the Piceance basin, Colorado: Boulder, University of Colorado, Ph.D. thesis, $170 \mathrm{p}$.

Stokes, W.L., 1944, Morrison formation and related deposits in and adjacent to the Colorado Plateau: Geological Society of America Bulletin, v. 55, p. 951-992.

1952, Lower Cretaceous in Colorado Plateau: American Association of Petroleum Geologists Bulletin, v. 36 , no. 9 , p. $1766-1776$.

Tschudy, R.H., Tschudy, B.D., and Craig, L.C., 1984, Palynological evaluation of Cedar Mountain and Burro Canyon Formations, Colorado Plateau: U.S. Geological Survey Professional Paper 1281, $21 \mathrm{p}$.

Van Wagoner, J.C., Posamentier, H.W., Mitchum, R.M., Jr., Vail, P.R., Sarg, J.F., Loutit, T.S., and Hardenbol, J., 1988, An overview of the fundamentals of sequence stratigraphy and key definitions, in Wilgus, C.K., and others, eds., Sea-level changes-An integrated approach: Society of Economic Paleontologists and Mineralogists Special Publication 42, p. 39-45.

Williams, G.D., and Stelck, C.R., 1975, Speculations on the Cretaceous paleogeography of North America, in Caldwell, W.G.E., ed., The Cretaceous System in the Western Interior of North America: Geological Association of Canada Special Paper 13, p. 1-20.

Williams, P.L., 1964, Geology, structure, and uranium deposits of the Moab quadrangle, Colorado and Utah: U.S. Geological Survey Miscellaneous Geologic Investigations Map 1-360, scale 1:250,000. 
Wilson, E.D., Moore, R.T., and Cooper, J.R., 1969, Geologic map of Arizona: Arizona Bureau of Mines and U.S. Geological Survey, scale 1:500,000.

Witkind, I.J., 1988, Geologic map of the Huntington $30^{\prime} \times 60^{\prime}$ quadrangle, Carbon, Emery, Grand, and Uintah
Counties, Utah: U.S. Geological Survey Miscellaneous Investigations Series Map I-1764, scale 1:100,000.

Young, R.G., 1960, Dakota Group of Colorado Plateau: American Association of Petroleum Geologists Bulletin, v. 44 , no. 2 , p. $156-194$. 

